\title{
Homocysteine and reactive oxygen species in metabolic syndrome, type 2 diabetes mellitus, and atheroscleropathy: The pleiotropic effects of folate supplementation Melvin R Hayden*1 and Suresh C Tyagi ${ }^{2}$
}

\author{
Address: ${ }^{1}$ Department of Family and Community Medicine University of Missouri Columbia, Missouri PO BOX 1140 Lk. Rd. 5-87 Camdenton, \\ Missouri 65020 USA and 2Department of Physiology and Biophysics 500 South Preston Street University of Louisville Louisville, Kentucky 40292 \\ USA \\ Email: Melvin R Hayden* - mrh29@usmo.com; Suresh C Tyagi - s0tyag01@louisville.edu \\ * Corresponding author
}

Published: 10 May 2004

Nutrition Journal 2004, 3:4
Received: 05 February 2004

Accepted: 10 May 2004

This article is available from: http://www.nutritionj.com/content/3/l/4

(c) 2004 Hayden and Tyagi; licensee BioMed Central Ltd. This is an Open Access article: verbatim copying and redistribution of this article are permitted in all media for any purpose, provided this notice is preserved along with the article's original URL.

\begin{abstract}
Homocysteine has emerged as a novel independent marker of risk for the development of cardiovascular disease over the past three decades. Additionally, there is a graded mortality risk associated with an elevated fasting plasma total homocysteine (tHcy). Metabolic syndrome (MS) and type 2 diabetes mellitus (T2DM) are now considered to be a strong coronary heart disease (CHD) risk enhancer and a CHD risk equivalent respectively. Hyperhomocysteinemia (HHcy) in patients with MS and T2DM would be expected to share a similar prevalence to the general population of five to seven percent and of even greater importance is: Declining glomerular filtration and overt diabetic nephropathy is a major determinant of tHcy elevation in MS and T2DM.

There are multiple metabolic toxicities resulting in an excess of reactive oxygen species associated with MS, T2DM, and the accelerated atherosclerosis (atheroscleropathy). HHcy is associated with an increased risk of cardiovascular disease, and its individual role and how it interacts with the other multiple toxicities are presented.

The water-soluble $B$ vitamins (especially folate and cobalamin-vitamin $B_{12}$ ) have been shown to lower HHcy. The absence of the cystathionine beta synthase enzyme in human vascular cells contributes to the importance of a dual role of folic acid in lowering thcy through remethylation, as well as, its action of being an electron and hydrogen donor to the essential cofactor tetrahydrobiopterin. This folate shuttle facilitates the important recoupling of the uncoupled endothelial nitric oxide synthase enzyme reaction and may restore the synthesis of the omnipotent endothelial nitric oxide to the vasculature.
\end{abstract}

\section{Introduction and background}

Homocysteine (Hcy) is a nonessential sulfur-containing amino acid and an intermediary metabolic product derived from the demethylated essential amino acid methionine (figure 1). 


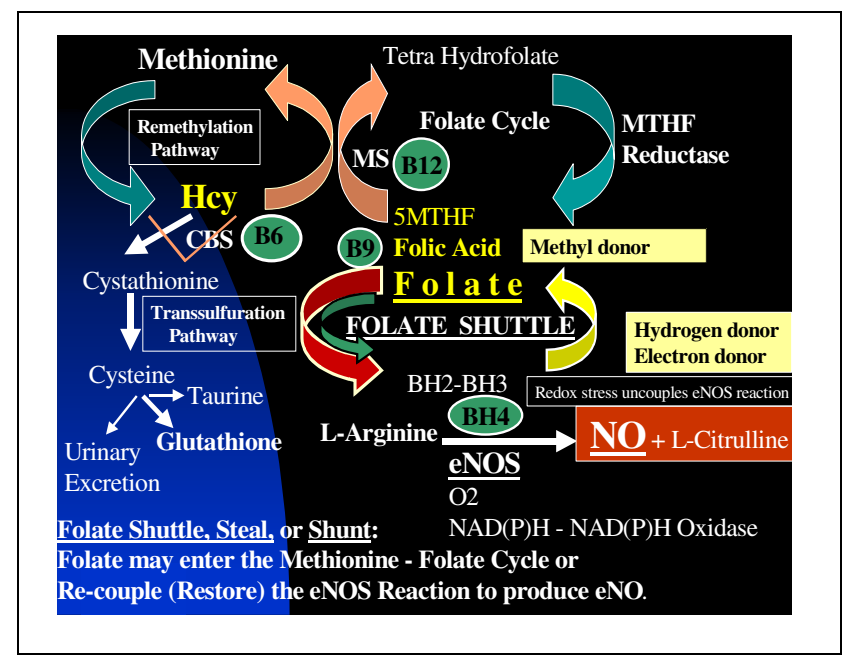

Figure I

Homocysteine metabolism: methionine - folate cycle and the folate shuttle Hcy is an intermediate metabolic product of methionine metabolism. Once methionine is demethylated, producing Hcy it can be further catabolized to cystathionine and cysteine via the transsulfuration pathway. This transsulfuration pathway is dependent on the cystathionine beta synthase enzyme (CBS) and vitamin $B_{6}$. Human vascular cells lack the CBS enzyme and therefore the transsulfuration pathway is not present. In the remethylation cycle termed the Methionine - Folate Cycle, folic acid (folate) serves as the methyl donor to convert Hcy to Methionine. This reaction is dependent on the Methionine Synthase (MS) enzyme and the cofactor vitamin $B_{12}$. Folate serves not only as a methyl donor but also as hydrogen and an electron donor. This hydrogen and electron donation capability renders folate as a dual source for stabilization of the tetrahydrobiopterin $\left(\mathrm{BH}_{4}\right)$ Cofactor of the endothelial nitric oxide synthase (eNOS) reaction producing the quintessential endothelial nitric oxide (eNO) and the additional function of being a local endothelial microenvironment antioxidant. These findings have led to the hypothesis of a Folate Shuttle phenomenon. As can be seen there may exist a relative endogenous endothelial folate deficiency resulting in a toxic effect of Hcy accumulation within endothelial cells as a result of this Folate Shuttle.

Since its discovery in 1932 by the 1955 Nobel Prize recipient Vincent DuVigneaud [1] and its association with premature arteriosclerotic (fibrotic) vascular disease described by Kilmer McCully in 1969 [2], Hcy has emerged as a novel marker of risk for cardiovascular disease.

In the past decade Hcy has become widely accepted as a novel risk marker associated with atherosclerotic cardiovascular disease (CVD) in the coronary, cerebral, and peripheral vascular beds. Additionally, it has been determined that hyperhomocysteinemia (HHcy) is an independent and a graded risk factor for the development of CVD [3-13]. The current role of Hcy as a causative factor still remains controversial and needs to be more fully elucidated.

The important role of oxidative - redox stress and HHcy is biologically plausible because Hcy promotes oxidant injury to vascular cells (particularly the endothelium and the eNOS enzyme reaction) through the auto-oxidation of Hcy, formation of Hcy mixed disulfides, interaction of Hcy thiolactones, and protein homocysteinylation [14$16]$.

Oxidation of two Hcy molecules yields the oxidized disulfide (homocystine), two protons $\left(\mathrm{H}^{+}\right)$, and two electrons $\left(e^{-}\right)$, while promoting the formation of reactive oxygen species (ROS). 


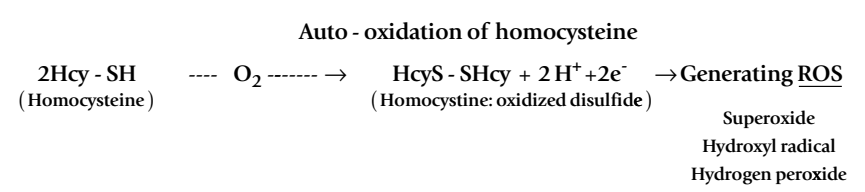

Also, formation of mixed disulfides contributes to the additional formation of ROS

$$
\begin{array}{ll}
\text { Hcy-SH + R-SH --- } \mathrm{O}_{2}------\rightarrow \text { Hcy-S-SR + H2O } & \rightarrow \text { ROS } \\
\text { Hcy-SH + R1-S-S-R2 } \leftarrow \rightarrow \text { R1-S-S-Hcy + R2-SH } & \rightarrow \text { ROS }
\end{array}
$$

$\mathrm{R}=$ any organic compound in the plasma with a thiol group (-SH) accessible to react with Hcy, such as proteins, cysteine, glutathionine, gamma-glutamylcysteine, or cystinylglycine.

Additionally, Hcy may undergo complicated rearrangements to form Hcy thiolactone (a cyclic thioester), which is chemically reactive and acylates free amino groups such as the side-chain lysine groups in proteins. In the process of forming homocysteinylated proteins further oxidative stress develops and homocysteinylated proteins become damaged and may lose their biological activity. This results in the modification of proteins and in particular the modification of low-density lipoproteins (LDL-cholesterol), which contribute to their retention within the intima and subsequent inflammatory foam cell formation associated with atherogenesis.

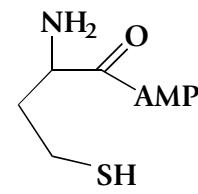

Aminoacyl-tRNA Synthetase Bound Hcy adenylate (Hcy AMP)

Jakubowski has recently been able to demonstrate that Hcy is now considered to be a protein amino acid in humans. In areas of turbulent blood flow the formation of Hcy-N-protein mediated by S-nitroso-Hcy may account for the observation that atherosclerosis originates mostly at branch points and flow dividers in arteries [17].

Recent controversial findings have been published in regards to post percutaneous coronary angioplasty (PTCA) restenosis, one trial has shown a decrease in restenosis and major adverse events of death, nonfatal myocardial infarction, and need for repeat revascularization [18-20], while others have shown no significant effect on the occurrence of restenosis [21-23].
A recent secondary prevention trial by Liem et al. [24] has shown no effect in cardiovascular risk reduction within 2 and now 4 years treatment with low dose folic acid supplementation in patients previously on statin therapy and stable coronary artery disease.

Regardless of the current controversies regarding Hcy as being an independent risk factor or merely a risk marker, Hcy has definitely emerged as one of the novel-multifactorial substrates, which interacts with conventional CVD risk factors of the atherosclerotic process $[25,26]$.

Numerous ongoing clinical trials have yet to determine if lowering Hcy by folic acid supplementation decrease the risk of cardiovascular events or cardiovascular mortality and these trials will be forthcoming within the next few years (table 1 ).

An attempt to shed some new light on the Hcy - HHcy story as it pertains to the metabolic syndrome (MS), prediabetes (PD), and overt type 2 diabetes mellitus (T2DM) and their association with the multiple metabolic toxicities resulting in an increase of reactive oxygen species (ROS) will be discussed.

Furthermore, an attempt to develop a hypothesis that HHcy is a marker of oxidative and redox stress, as a result of an endogenous folate shuttle, which results in a relative endogenous endothelial folate deficiency due to a folate shuttle phenomenon to preferentially run the endothelial nitric oxide synthase (eNOS) reaction will be explored.

The lack of Hcy catabolic transsulfuration in human vascular cells provides an even more important role for the folate shuttle phenomenon in vascular cells. This would result in a relative endogenous endothelial folate deficiency to operate the remethylation pathway via the methionine - folate cycle culminating in vascular cell HHcy.

This folate shuttle phenomenon could also be operative in hypertension and non-diabetic atherosclerosis due to an associated uncoupling of the eNOS enzyme reaction with decreased endothelial nitric oxide (eNO) production and resultant endothelial cell dysfunction.

There are multiple clinical factors associated with HHcy (table 2)), as well as, multiple damaging effects to the vascular system (table 3 ). In MS, PD, and T2DM there are multiple injurious stimuli to the endothelial cell (including HHcy), and these substrate interactions result in accelerated atherosclerosis $\rightarrow$ atheroscleropathy (figure 2).

While the liver normally contains the full complement of metabolic enzymes to handle HHcy through the remeth- 
Table I: Homocysteine lowering intervention trials for the prevention of CVD.

I. SEARCH: Study of the effectiveness of additional reduction in cholesterol and homocysteine. University of Oxford, England.

2. PACIFIC: Prevention with a combined inhibitor of folate in coronary heart disease. University of Sydney, Australia.

3. WACS: Women's antioxidant and cardiovascular disease study. Harvard Medical School, USA.

4. CHAOS-2: Cambridge heart antioxidant study. University of Cambridge, England.

5. NORVITE: Norwegian study of homocysteine lowering with B-vitamins in myocardial infarction. University of Tromso, Norway.

6. BERGEN: Bergen vitamin study. University of Bergen, Norway.

7. HOPE-2: Health outcome and prevention evaluation number 2. Canada.

8. VISP: Vitamin intervention for stroke prevention. Wake Forest University, USA.

9. VITATOPS: Vitamins to prevent strokes. Perth, Australia.

I 0. IST-2: International strokes trial number 2. Auckland, New Zealand.

ylation and the transsulfuration catabolic metabolic pathway, it is limited in human vascular cells. Vascular cells in particular do not express cystathionine beta synthase (CBS), the first enzyme of the hepatic transsulfuration pathway; nor do they express the enzyme betaine homocysteine methyltransferase (BHMT), which catalyzes the alternate remethylation pathway in the liver using betaine as a substrate $[27,28]$.

Therefore in vascular cells, Hcy metabolism is limited to the B12 - folate dependent remethylation pathway catalyzed by methionine synthase of the methionine-folate cycle. Thus, vascular cells and particularly endothelial cells may be especially vulnerable to the higher levels of circulating and endogenous Hcy found in patients with HHcy.

This makes the endothelial cell and smooth muscle cells quite vulnerable to the previously discussed oxidative stress of HHcy. In the MS, PD, and overt T2DM this would definitely result in an additive - synergistic effect to the associated multiple metabolic toxicities and the elevated substrates of the A-FLIGHT acronym (table 4).

These findings would help to explain the increased mortality and cardiovascular disease associated with HHcy, especially in T2DM [29-31]. In concluding this section it is important to note that:

HHcy is associated with an increased risk of cardiovascular disease, especially in non-insulin-dependent diabetes mellitus [8].

\section{Reactive oxygen species: "toxic oxygen"}

ROS consist primarily of the oxygen free radicals (superoxide $\left[\mathrm{O}_{2}^{-\bullet}\right]$, hydroxyl radical $\left[-\mathrm{OH}^{\bullet}\right]$, peroxynitrite $\left.\left[\mathrm{ONOO}^{\bullet}-\right]\right)$, the potent oxidizing agents of the non-radical family (peroxide $\left[\mathrm{H}_{2} \mathrm{O}_{2}\right]$ and hypochlorous acid [HCLO]), and the organic analogues, which include reactive nitrogen species: specifically, peroxynitrite [ONOO•-] (table 5).
It has been known for some time that ROS are detrimental and toxic to cells and tissues as a result of injury to lipids, nucleic acids, and proteins: (A). Lipid peroxidation of membranes (loss of membrane function and increased permeability) and generation of lipid autoperoxidation reactions. (B). DNA damage leading to mutation and death. (C). Cross linking or vulcanization of sulfhydryl rich proteins (leading to stiff aged proteins specifically collagen of the extracellular matrix) [32].

Both intracellular and extracellular antioxidants play important roles in neutralizing these toxic oxygen molecules. The endogenous antioxidant enzyme family consists primarily of superoxide dismutase (SOD), catalase, glutathione peroxidase and the tri-peptide (gammaL-glutamyl-L-cysteintyl-glycine) glutathione or (GSH), and free circulating thiols containing the sulfhydryl group $(-\mathrm{SH})$ (table 6). These antioxidants are found to be systemically depleted in the clinical setting of T2DM and evidence is present for their depletion in atheromatous lesions $[31,32]$.

There are multiple metabolic toxicities associated with MS, PD, T2DM, and their companion: accelerated atherosclerosis (atheroscleropathy). These multiple metabolic toxicities can be conveniently grouped in an acronym termed the A-FLIGHT toxicities (table 4). Each of these toxicity substrates result in the excessive production of ROS responsible for the damaging effects of oxidative redox stress.

Not only are ROS involved in the development of autoimmune type 1 diabetes mellitus and T2DM but also play an important role in the long-term development of the associated complications: atheroscleropathy, diabetic cardiomyopathy, intimopathy, nephropathy, neuropathy, endotheliopathy, and retinopathy. 


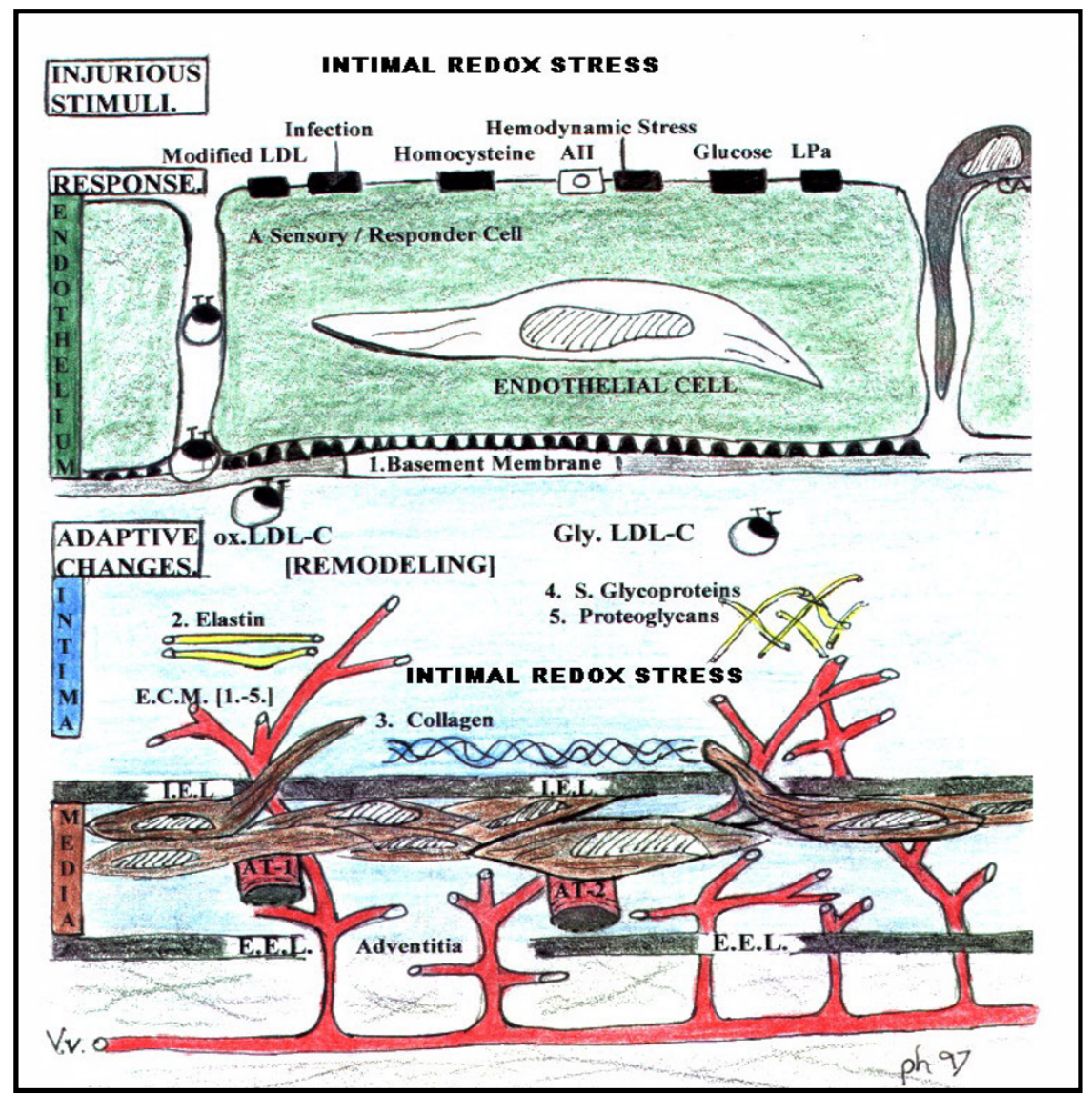

\section{Figure 2}

Multiple injurious stimuli to the endothelium, intima, media, and adventitia The endothelial cell is exposed to multiple injurious stimuli consisting of: modified LDL-cholesterol, various infection insults (viral and bacterial), angiotensin II, hemodynamic stress, LPa, glucose, homocysteine, and intimal redox stress or reactive oxygen species. As discussed in this review, the toxicity of homocysteine may act alone as well as in concert with the other multiple injurious stimuli to injure the endothelium resulting in endothelial cell dysfunction. Especially in the MS, PD, overt T2DM, and atheroscleropathy. It is of importance to note that native LDL-cholesterol is not atherogenic to the vascular intima. The process of oxidation, glycation, glycoxidation, or homocysteinylation must modify LDL-cholesterol in order to become atherogenic. Thus, the importance of the multiple injurious stimuli acting alone and synergistically to modify LDL-cholesterol and accelerate angiogenesis as seen in the accelerated atherosclerosis associated with MS, PD, and overt T2DM termed atheroscleropathy.

Hyperhomocysteinemia and reactive oxygen species in insulin resistance, metabolic syndrome, type 2 diabetes mellitus, and atheroscleropathy

There are multiple metabolic toxicities associated with MS, PD, and overt T2DM, which are associated with the production of ROS. These toxic substrates and their associated ROS have been conveniently grouped together to form the acronym: A-FLIGHT toxicities (table 4).
The general population of patients with MS, IR, PD, and overt T2DM will, in allprobability, have a similar frequency of the common polymorphism affecting the folate-dependent, thermolabile gene coding for the 5, 10methylene tetrahydrofolate reductase MTHFR) ((C677T, $\mathrm{Ala} \rightarrow \mathrm{Val})$ is associated with a decreased activity of the enzyme with subsequent mild to moderate HHcy, which occurs in $10-15 \%$ of the general population [33-35]. 
Table 2: CLINICAL FACTORS ASSOCIATED WITH HHcy

\begin{tabular}{|c|c|}
\hline I. Age and Gender: & $\begin{array}{l}\text { HHcy is associated with aging and male gender. Females typically have Hcy levels } 20 \% \\
\text { lower than men until menopause. After menopause fasting levels of Hcy rise to those } \\
\text { of men of similar age. }\end{array}$ \\
\hline $\begin{array}{l}\text { 2. Genetic: Not only deficiency but also dysfunction } \\
\text { secondary to various gene polymorphisms. }\end{array}$ & $\begin{array}{l}\text { I. Cystathionine Beta Synthase deficiency. } \\
\text { 2. 5, I0-methylenetetrahydrofolate reductase deficiency. } \\
\text { 3. Methionine synthase deficiency (including abnormalities in cobalamin metabolism). } \\
\text { 4. Methylenetetrahydrofolate homocysteine methyltransferase deficiency. }\end{array}$ \\
\hline 3. Renal Function: & $\begin{array}{l}\text { Hcy levels increase with elevations of creatinine levels. Due to impaired renal } \\
\text { excretion (decreased glomerular filtration rate) and or impaired metabolism. }\end{array}$ \\
\hline 4. Nutritional Status: & $\begin{array}{l}\text { Decreased vitamin cofactors (folate, vitamin } B_{12} \text {, and } B_{6} \text { ). Aging - Alterations in gastric } \\
\text { mucosa affecting intrinsic factor, inflammatory bowel diseases such as Crohn's disease } \\
\text { and Ulcerative colitis, celiac disease, lymphomas and amyloidosis to name a few. }\end{array}$ \\
\hline 5. Disease States: & $\begin{array}{l}\text { Hypothyroidism. Carcinomas (breast, ovary, and pancreas in particular). Chronic } \\
\text { renal failure from any cause especially diabetic and hypertensive nephropathy. } \\
\text { Systemic lupus erythematous. Psoriasis. Solid organ transplantation. Malabsorption } \\
\text { syndromes associated with nutritional status: Number } 4 \text {. }\end{array}$ \\
\hline 6. Medications: & $\begin{array}{l}\text { Anticonvulsants, such as phenytonin, Methotrexate, Theophylline and other } \\
\text { bronchodilaors of the phosphodiesterase inhibitor class, which interfere with } \\
\text { pyridoxal phosphate synthesis. Nitrous oxide, L-dopa, Carbamazepine, Niacin, } \\
\text { Fibrates, and Bile acid resins to name a few. }\end{array}$ \\
\hline $\begin{array}{l}\text { 7. Endothelial Cell Dysfunction: Any cause for a } \\
\text { decrease in eNOS enzyme or eNO bioavailability. }\end{array}$ & $\begin{array}{l}\text { Any cause of endothelial cell dysfunction could result in HHcy if one accepts the } \\
\text { endogenous endothelial folate shuttle HYPOTHESIS. }\end{array}$ \\
\hline
\end{tabular}

Table 3: DAMAGING EFFECTS OF HOMOCYSTEINE

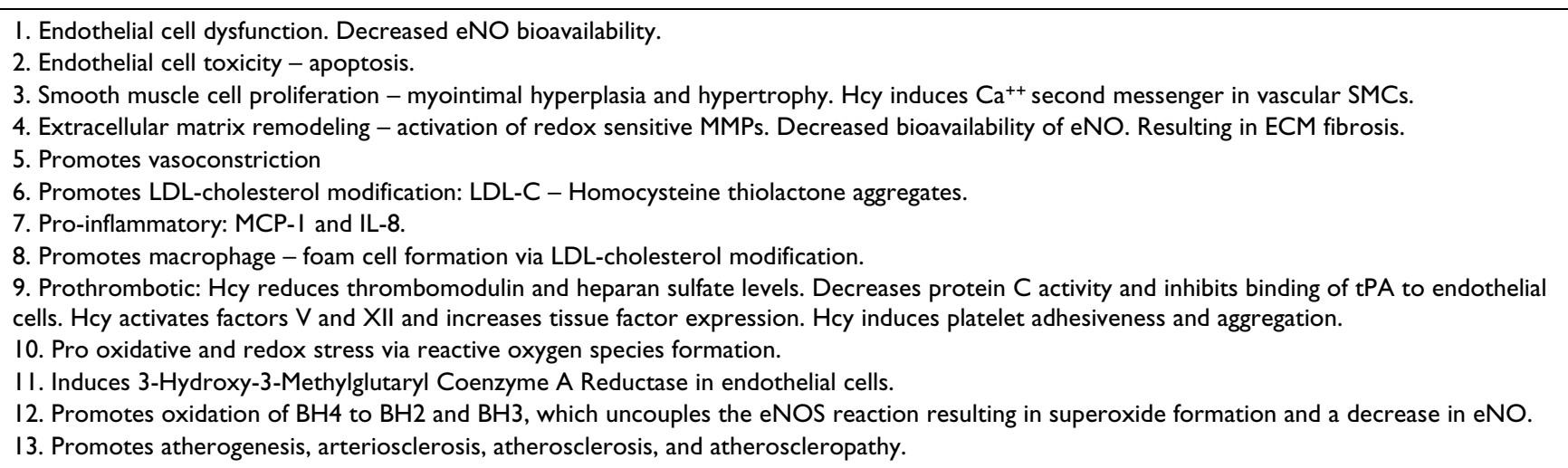

This gene polymorphism is especially important in those individuals with a decrease in dietary folate. In these patients mild to moderate HHcy can be improved with dietary and folate supplementation, which improves endothelial-dependent endothelial cell dysfunction [36]. In the general population, mild to moderate HHcy occurs in approximately $5-7 \%$ [9].

HHcy is not usually present as a direct result of MS, PD, and T2DM unless there is an associated development of impaired renal function. As nephropathy develops, there is an associated elevation of total Hcy associated with a decline in glomerular filtration rate [37].
In the early latent Stage I and transitional Stage II of T2DM (table 7) homocysteine may actually be lower than expected. Rosolova $\mathrm{H}$ et al. have found an unexpected inverse relationship between IR and serum Hcy in a population of healthy subjects with insulin resistance. They have attributed this finding to the associated increase in the glomerular hyperfiltration [38].

IR and PD (Stages I, II, and early Stage III) are associated for a period of time with hyperinsulinemia, hyperproinsulinemia, and hyperamylinemia and glomerular hyperfiltration and hyperperfusion. Recently, the nitric oxide system has been shown to be involved in glomerular hyperfiltration in Japanese normo- and micro-albuminu- 
Table 4: MULTIPLE METABOLIC TOXICITIES IN MS AND T2DM: THE A-FLIGHT ACRONYM

\begin{tabular}{|c|c|c|c|c|c|}
\hline & Initiator & Metabolic Defect & Metabolic mediator & Functional mediator & Consequence \\
\hline \multirow[t]{8}{*}{ A } & $\begin{array}{l}\text { AMYLIN (Co-secreted - Co- } \\
\text { packaged within the insulin secretory } \\
\text { granule) by the islet Beta cell. } \\
\text { Insulin's "Fraternal Twin" Elevated in } \\
\text { MS, PD, and Early T2DM) }\end{array}$ & Hyperamylinemia & Activation of ANG II & $\begin{array}{l}\text { PKC Signal Transduction } \\
\text { Islet Amyloid IAPP Islet } \\
\text { aggregation and deposition. } \\
\text { Beta cell apoptosis - Beta } \\
\text { cell defect. }\end{array}$ & $\begin{array}{l}\text { ROS IAPP Amyloid in islets } \\
\text { contributing to Beta Cell } \\
\text { defect. Possible deposition } \\
\text { in the intima, mesangium, } \\
\text { neuronal unit, and } \\
\text { myocardial. REMODELING }\end{array}$ \\
\hline & $\begin{array}{l}\text { ANG II Via RAAS activation In MS, } \\
P D \text {, and T2DM }\end{array}$ & Ang II Excess & $\begin{array}{l}\text { Ang II Excess Most potent } \\
\text { stimulus for: Activation of } \\
\text { Vascular membrane bound } \\
\text { NAD(P)H Oxidase Enzyme }\end{array}$ & $\begin{array}{l}\text { PKC Signal Transduction. } \\
\text { Superoxide production. } \\
\text { Uncoupling of the eNOS } \\
\text { reaction. TGF beta-I } \\
\text { activation }\end{array}$ & $\begin{array}{l}\text { ROS NAD(P)H oxidase } \\
\text { Derived Superoxide } \\
\text { Myocardial, Renal, Intimal, } \\
\text { Retinal, and Neuronal } \\
\text { remodeling }\end{array}$ \\
\hline & $\begin{array}{l}\text { AGE Advanced Glycation } \\
\text { Endproducts AFE Advanced } \\
\text { fructosylation endproducts }\end{array}$ & $\begin{array}{l}\text { AGE / AFE See Glucotoxicity } \\
\text { (G) RAGE activation Receptor } \\
\text { for } \mathrm{AGE}\end{array}$ & $\begin{array}{l}\text { Protein Cross - linking / } \\
\text { Dysfunction RAGE Receptor } \\
\text { for AGE }\end{array}$ & $\begin{array}{l}\text { Matrix Defects Signal } \\
\text { Transduction Matrix Defects } \\
\text { Signal Transduction }\end{array}$ & $\begin{array}{l}\text { ROS Myocardial, Renal, } \\
\text { Intimal, Retinal, Neuronal - } \\
\text { Endoneurial Fibrosis }\end{array}$ \\
\hline & $\begin{array}{l}\text { Advanced Lipoxidation Endproducts } \\
\text { (ALE) }\end{array}$ & ALE & Protein Cross - linking & $\begin{array}{l}\text { Matrix Defects Signal } \\
\text { Transduction }\end{array}$ & ROS Matrix Remodeling \\
\hline & $\begin{array}{l}\text { AntioxidantEnzymes: Antioxidant } \\
\text { reserve compromised }\end{array}$ & $\begin{array}{l}\text { Reduced - Dysfunctional } \\
\text { eNOS, SOD, GPx, GSH, } \\
\text { Catalase, and Vit. C. }\end{array}$ & Decreased NO & $\begin{array}{l}\text { Decreased NO REDOX } \\
\text { STRESS }\end{array}$ & ROS REDOX STRESS \\
\hline & $\frac{\text { AntioxidantEnzymes: }}{\text { antioxidant network }}$ Absence of & $\begin{array}{l}\text { IMPAIRED eNOS L-arginine } \\
\mathrm{BH} 4\end{array}$ & Decreased NO & Decreased NO & ROS Decreased NO \\
\hline & $\begin{array}{l}\text { AGING: Accumulation of multiple } \\
\text { metabolic toxicities } \rightarrow \text { ROS }\end{array}$ & $\begin{array}{l}\text { Increased Ox-LDL-C, } \\
\text { TNFalpha, Capase 3, } \\
\text { Glomerulosclerosis. }\end{array}$ & Decreased NO: & Decreased NO & $\begin{array}{l}\text { ROS Inflammation, } \\
\text { Apoptosis }\end{array}$ \\
\hline & Atherosclerotic Nephropathy & $\begin{array}{l}\text { ROS beget ROS } \\
\text { Atheroscleropathy }\end{array}$ & $\begin{array}{l}\text { Decreased NO Self } \\
\text { perpetuating Decreased NO }\end{array}$ & $\begin{array}{l}\text { Decreased NO Athero - } \\
\text { emboli Activated Platelets } \\
\text { See Thrombotic Tox. }\end{array}$ & $\begin{array}{l}\text { ROS beget ROS Decreased } \\
\text { NO }\end{array}$ \\
\hline $\mathrm{F}$ & Free fatty acid toxicity & Elevated FFA & LC acyl-CoA's & Mitochondrial Defects & ROS Cytotoxicity \\
\hline L & $\begin{array}{l}\text { Lipotoxicity Lipid Triad FFA ALE } \\
\text { Long chain acyl-COA's }\end{array}$ & $\begin{array}{l}\text { Increased VLDL - VLDL } \\
\text { Triglycerides and Small dense } \\
\text { atherogenic LDL-Cholesterol } \\
\text { with Decreased HDL- } \\
\text { Cholesterol LIPID TRIAD }\end{array}$ & $\begin{array}{l}\text { LC acyl-CoA's Fat } \\
\text { Accumulation }\end{array}$ & $\begin{array}{l}\text { Non Adipose Accumulation } \\
\text { of Fat (LC acyl -CoA's) in } \\
\text { Adipose and Non Adipose } \\
\text { Tissue }\end{array}$ & $\begin{array}{l}\text { ROS Accumulation of fat in } \\
\text { non adipose tissues resulting } \\
\text { in Ceramide induced: } \\
\text { Cytotoxicity }\end{array}$ \\
\hline \multirow[t]{3}{*}{ I } & $\begin{array}{l}\text { Insulin toxicity ENDOGENOUS } \\
\text { Insulin Resistance }\end{array}$ & $\begin{array}{l}\text { Hyperinsulinemia } \\
\text { Hyperamylinemia in : MS, PD, } \\
\text { EARLY T2DM Glut } 4 \text { is NO } \\
\text { dependent Redox sensitive } \\
\text { pathway }\end{array}$ & $\begin{array}{l}\text { Ang II Increase \# AT-I } \\
\text { receptors Cross-talk with } \\
\text { AT-I Increase FFA Increase } \\
\text { PAI-I Increase Sympathetic } \\
\text { tone and activity Increased } \\
\mathrm{Na}+\text { and } \mathrm{H} 2 \mathrm{O} \text { reabsorption } \\
\text { Increase Volume and Blood } \\
\text { Pressure Hypertension Hype }\end{array}$ & $\begin{array}{l}\text { NAD(P)H REDOX STRESS } \\
\text { SIGNAL PATHWAYS PI3 } \\
\text { Kinase / Akt (Protein kinase } \\
\text { B) } \rightarrow \text { MAP Kinase Shunt }\end{array}$ & $\begin{array}{l}\text { ROS ROS ROS Extracellular } \\
\text { Matrix Remodeling Islet, } \\
\text { intimal, renal, myocardial, } \\
\text { and neuronal. }\end{array}$ \\
\hline & $\begin{array}{l}\text { Inflammation toxicity. "Inflammatory } \\
\text { Cycle" (figure 5) }\end{array}$ & $\begin{array}{l}\text { Activation of the innate } \\
\text { immune system: IL-6, IL-8, } \\
\text { TNF alpha Macrophage (MPO) } \\
\rightarrow \text { Hypochlorous Acid } \\
\text { Superoxide } \mathrm{O}_{2}^{\circ}\end{array}$ & $\begin{array}{l}\text { Acute Phase Reactants: C- } \\
\text { Reactive Protein Serum } \\
\text { Amyloid A Fibrinogen }\end{array}$ & $\begin{array}{l}\text { NF kappa B Cellular } \\
\text { Adhesion Molecules: ICAM, } \\
\text { VCAM, and MCP-I }\end{array}$ & $\begin{array}{l}\text { ROS Inflammation begets } \\
\text { Inflammation " } \\
\text { INFLAMMATORY CYCLE " } \\
\text { (figure 5) ROS beget ROS }\end{array}$ \\
\hline & Insulin deficiency & OVERT T2DM & $\begin{array}{l}\text { GLUCOTOXICITY } \\
\text { POLYOL SORBITOL } \\
\text { PATHWAY }\end{array}$ & $\begin{array}{l}\text { REDUCTIVE STRESS } \\
\text { NADH > NAD+ } \\
\text { PSEUDOHYPOXIA }\end{array}$ & ROS \\
\hline \multirow[t]{10}{*}{ G } & Glucotoxicity & Glycation / AGE & See above & See above & See above \\
\hline & & & Protein inactivation & Receptor-ligand defects & $\begin{array}{l}\text { Dysfunctional Signal } \\
\text { Transduction }\end{array}$ \\
\hline & & & NO quenching & Vasoconstriction & Ischemia/Hypoxia ROS \\
\hline & & & Macrophage Activation & $\begin{array}{l}\text { Increased Cytokines, TGF- } \\
\text { Beta }\end{array}$ & Cytotoxicity ROS \\
\hline & & & Free Radical Formation & REDOX STRESS & Cytotoxicity ROS \\
\hline & & Auto-oxidation & Free Radical Formation & REDOX STRESS & Cytotoxicity ROS \\
\hline & $\begin{array}{l}\text { ORIGIN OF REDUCTIVE STRESS ! } \\
\text { REDUCTIVE STRESS! }\end{array}$ & $\begin{array}{l}\text { Polyol Sorbitol Pathway (eNO } \\
\text { inhibits Aldose Reductase) }\end{array}$ & $\begin{array}{l}\text { Increased NADH Lactate } \\
\text { Reductive Stress }\end{array}$ & $\begin{array}{l}\text { REDOX STRESS Decreased } \\
\text { NO Pseudohypoxia }\end{array}$ & $\begin{array}{l}\text { Cytotoxicity ROS Ischemia/ } \\
\text { Hypoxia }\end{array}$ \\
\hline & & & Decreased Taurine & REDOX STRESS & ROS Cytotoxicity \\
\hline & & Increased DAG & Increased PKC & Signal Transduction & Ischemia ROS \\
\hline & Glucotoxicity & Glucotoxicity & Polyol - Sorbitol Pathway & $\begin{array}{l}\text { PAS + material Interstitium, } \\
\text { Basement Membrane }\end{array}$ & $\begin{array}{l}\text { Remodeling - } \\
\text { Cardiomyopathy CHF } \\
\text { Diastolic Dysfunction }\end{array}$ \\
\hline $\mathrm{H}$ & $\begin{array}{l}\text { Hypertension Toxicity } \\
\text { Homocysteine Toxicity }\end{array}$ & $\begin{array}{l}\text { RAAS activation HHcy NO } \\
\text { quenching and NEW: PPAR } \\
\text { interaction. }\end{array}$ & $\begin{array}{l}\text { Ang II Decreased GPx, } \\
\text { DDAH with resultant }{ }^{\wedge} \\
\text { ADMA }\end{array}$ & $\begin{array}{l}\text { NAD(P)H REDOX STRESS } \\
\text { ^ ROS, O2', ONOO', } \\
\text { nitrotyrosine }\end{array}$ & $\begin{array}{l}\text { ROS Decreased NO, } \\
\text { Endothelial Cell toxicity, } \\
\text { dysfunction, and apoptosis }\end{array}$ \\
\hline $\mathrm{T}$ & $\begin{array}{l}\text { Triglyceride Toxicity Thrombotic } \\
\text { Toxicity Taurine (antioxidant) } \\
\text { depletion }\end{array}$ & Triglyceride - FFA exchange & $\begin{array}{l}\text { See FFA - Lipotoxicity above } \\
\text { eNOS uncoupling }\end{array}$ & $\begin{array}{l}\text { REDOX STRESS Activated } \\
\text { Platelets PAI-I elevation } \\
\text { Fibrinogen elevated. } \\
\text { Decreased NO }\end{array}$ & ROS Athero-emboli ROS \\
\hline
\end{tabular}


Table 5: Origin, enzymatic pathways of reactive oxygen species, and their oxidized products.

\begin{tabular}{|c|c|c|}
\hline Origin - Location Enzymatic Pathway & ROS Potent Oxidants & PRODUCTS Oxidized lipids and Proteins \\
\hline Mitochondrial Respiratory Chain & $\mathrm{O}_{2} \cdot-\mathrm{OH}^{\cdot}$ & $\begin{array}{l}\text { Oxidized lipids, proteins, nucleic acids, and autoxidation } \\
\text { byproducts. }\end{array}$ \\
\hline $\begin{array}{l}\text { Inflammatory Macrophage Membraneous } \mathrm{NAD}(\mathrm{P}) \mathrm{H} \\
\text { Oxidase }\end{array}$ & $\mathrm{O}_{2} \cdot \mathrm{OH} \cdot \mathrm{H}_{2} \mathrm{O}_{2}$ & $\begin{array}{l}\text { Advanced Lipoxidation Endproducts (ALE) Ortho o-tyrosine } \\
\text { Meta m- tyrosine }\end{array}$ \\
\hline Granular Myeloperoxidase (MPO) & Hypochlorous Acid $\mathrm{HOCL}$ (bleach) ${ }^{\cdot} \mathrm{Tyr} \mathrm{NO}_{2} \cdot$ & 3-Chlorotyrosine di-Tyrosine $\mathrm{NO}_{2}$-Tyrosine (Nitrotyrosine) \\
\hline $\begin{array}{l}\text { Macrophage Nitric Oxide Synthase (NOS) Inducible } \\
\text { (iNOS) Large bursts uncontrolled }\end{array}$ & ONOO' & $\mathrm{NO}_{2}-\mathrm{Tyr}$ (Nitrotyrosine) \\
\hline \multicolumn{3}{|l|}{ Endothelial Cell } \\
\hline $\begin{array}{l}\text { Nitric Oxide Synthase (NOS) Constitutive (cNOS) eNOS } \\
\rightarrow \text { NO nNOS } \rightarrow \text { NO Small bursts (puffs) controlled }\end{array}$ & $\mathrm{NO}+\mathrm{O}_{2} \cdot \rightarrow \mathrm{ONOO}^{\prime} \mathrm{ONOO}$ & $\mathrm{NO}_{2}-\mathrm{Tyr}$ (Nitrotyrosine) $\mathrm{NO}_{2}-\mathrm{Tyr}$ \\
\hline eNOS derived NO & NO: the GOOD & $\begin{array}{l}\text { Natural Occurring, Local Occurring, Chain Breaking } \\
\text { Antioxidant }\end{array}$ \\
\hline Superoxide & $\underline{\mathrm{O}}_{\underline{2}}:$ : the BAD & \\
\hline Peroxynitrite & ONOO: : the UGLY & \\
\hline Hypochlorous acid & $\overline{\mathrm{HCLO}}$ : the UGLY & \\
\hline $\begin{array}{l}\text { Restoration of endothelial derived NITRIC OXIDE Via the } \\
\text { eNOS reaction.. }\end{array}$ & $\begin{array}{l}\text { ANTIOXIDANT ANTIREDOXIDANT } \rightarrow \rightarrow \\
\rightarrow\end{array}$ & Prevention of the devastating effects of ROS. \\
\hline
\end{tabular}

Table 6: Antioxidants: catalytic - enzymatic inactivation of free radicals.

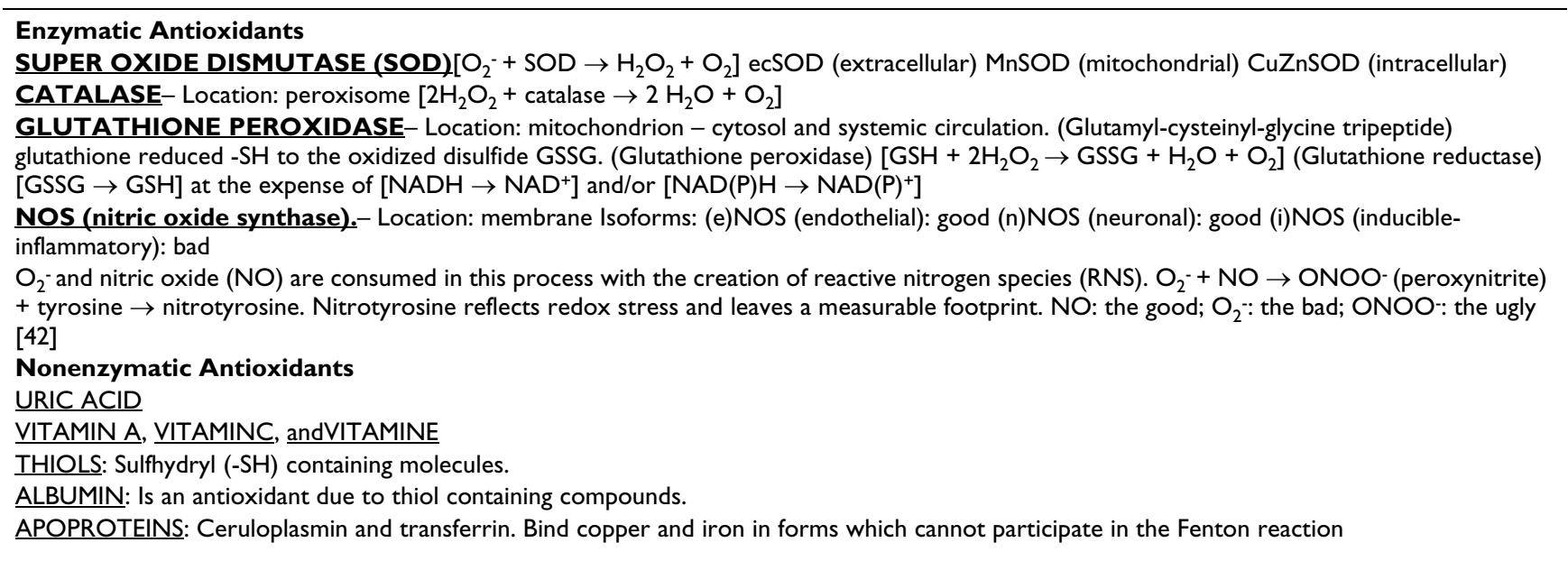

ric patients with T2DM and early stages of diabetic nephropathy [39]. Hiragushi K et al. were able to demonstrate an increase staining of eNOS enzyme (in glomerular endothelial cells) in microalbuminuric T2DM patients in comparison to non-diabetic control subjects.

This adaptive early response results in glomerular enlargement and an increase in the glomerular filtration rate [40]. Additionally, Apakkan Aksun S et al. found that serum and urine nitric oxide levels were elevated, as well as, plasma malanodialdehyde (MDA), which points to the importance of oxidative stress in patients with T2DM. These authors feel that the high nitric oxide levels may lead to hyperfiltration and hyperperfusion, which in turn leads to an increase in urinary albumin excretion and thus causes progression of nephropathy in early T2DM [41].
Over time (Stages III-V, table 7) there is an increase in glucotoxicity (initially postprandial Stage III and fasting in Stage IV), as well as, an increase in redox and oxidative stress to the glomerular endothelium. This damage is associated with lipid peroxides, free fatty acids, and activation of Ang II as a result of hyperinsulinemia, hyperproinsulinemia, hyperamylinemia and the totality of reactive oxygen species associated with the A-FLIGHT toxicities.

The activation of Ang II would be associated with the activation of the membranous $\mathrm{NAD}(\mathrm{P}) \mathrm{H}$ oxidase enzyme and generation of superoxide with its effect on endothelial cell dysfunction and uncoupling of the eNOS reaction. Over time, this would result in decreases in eNO and loss of a natural occurring local antioxidant network within the glomerular endothelial microenvironment. 
Table 7: The Five Stages of T2DM:

\begin{tabular}{|c|c|}
\hline \multicolumn{2}{|r|}{ The Natural Progressive History of T2DM. } \\
\hline \multirow[t]{8}{*}{ I. } & LATENT STAGE:[EARLY] \\
\hline & Insulin Resistance: \\
\hline & Genetic Component \\
\hline & Environmental component. Modifiable: obesity/sedentary life style. Nonmodifiable: aging \\
\hline & Beta Cell Defect: (Dysfunction) \\
\hline & Genetic ....... Abnormal processing, storage or secretion. \\
\hline & Intracellular/extracellular oligomers of Islet Amyloid toxicity to the Beta Cell. Abnormal processing, storage or secretion \\
\hline & Islet Amyloid: Diffusion Barrier: Secretory Defect: Intra Islet Absorptive Defect: \\
\hline \multirow[t]{5}{*}{ II. } & TRANSITION STAGE:[MIDDLE] \\
\hline & Persistent Hyperinsulinemia, Hyperproinsulinemia. $\rightarrow$ Ang II Accelerated Atherosclerosis \\
\hline & Persistent Hyperamylanemia. $\rightarrow$ Angll Accelerated Atherosclerosis \\
\hline & Continued remodeling of the endocrine pancreas (amyloid). \\
\hline & $\begin{array}{l}\text { Beta cell displacement, dysfunction, mass reduction due to the toxic effect of IAPP oligomers and the progressive developing diffusion } \\
\text { barrier. }\end{array}$ \\
\hline \multirow[t]{5}{*}{ III. } & $\begin{array}{l}\text { IGT STAGE (Impaired Glucose Tolerance):[LATE] "Pre-diabetes" Human Health Services (HHS) and American Diabetes } \\
\text { Association (ADA) term. }\end{array}$ \\
\hline & [Start treatment at this time] \\
\hline & Diagnose earlier: rejuvenation of the 2 hour glucose tolerance blood sugar $140-199 \mathrm{mg} / \mathrm{dl}$ \\
\hline & $\begin{array}{l}\text { Increased insulin resistance [Feeds forward] > Glucotoxicity [Feeds forward] > Insulin resistance [Feeds forward] > Glucotoxicity: } \\
\text { creating a vicious cycle. }\end{array}$ \\
\hline & $\begin{array}{l}\text { Islet amyloid. Increasing beta cell defect. Loss of beta cell mass with displacement. (Remodeling of islet architecture including extracellular } \\
\text { matrix). Beta cell loss centrally. }\end{array}$ \\
\hline \multirow[t]{4}{*}{ IV. } & $\begin{array}{l}\text { IFG STAGE (Impaired Fasting Glucose):[LATER] "Pre-diabetes" Human Health Services (HHS) and American Diabetes Association } \\
\text { (ADA) term. }\end{array}$ \\
\hline & Blood sugar ranging $[110-125 \mathrm{mg} / \mathrm{dL}]$ \\
\hline & *ADA new cut point IFG Nov 2003: [100-1 $25 \mathrm{mg} / \mathrm{dl}]$ \\
\hline & $\begin{array}{l}\text { Impaired hepatic glucose production: Increasing global insulin resistance (hepatic) with subsequent gluconeogenesis. Feeding } \\
\text { forward in the vicious cycle to accelerate insulin resistance globally. }\end{array}$ \\
\hline V. & $\begin{array}{l}\text { OVERT STAGE: [TOO LATE] FBG I } 26 \text { or greater: Random or } 2 \text { hour OGTT } 200 \text { or }> \\
\text { [50\% loss of beta cell function at the time of clinical diagnosis }]\end{array}$ \\
\hline & Use medications that do not increase endogenous insulin or amylin. Use combination therapy. Start treatment at stage III-IV (IGT-IFG). \\
\hline . & Paradigm Shift. $\rightarrow$ Diagnose Early $\rightarrow$ Start treatment Early $\rightarrow$ Stage III: IGT. \\
\hline
\end{tabular}

Glucotoxicity is associated with advanced glycosylation endproducts (AGEs) and their receptor (RAGE), activation of aldose reductase of the polyol-sorbitol pathway, activation of protein kinase C (PKC) isoforms, and transforming growth factor beta (TGFbeta). Once these glucotoxic mechanisms are in play and overt diabetic nephropathy with associated glomerulosclerosis and remodeling has developed, there will be a progressive decrease in glomerular filtration. These changes will result in Hcy elevation [37].

Thus, HHcy plays an extremely important role for additional oxidative-redox stress regarding the accelerated cardiovascular disease observed in diabetic patients on dialysis [42].

HHcy is thought to induce an oxidative inactivation of endothelial nitric oxide, in part by inhibiting or consuming the expression of cellular glutathione peroxidase (GPx). In heterozygous cystathionine beta-synthase deficient -/+ mice, Weiss et al. were able to restore endothelial cell function by increasing cellular thiols and reduced glu- tathione pools and increasing GPx activity with restoration of the endothelial function [43].

The ensuing cellular redox stress is magnified and total Hcy consumes $\mathrm{NO}$ by the indirect process of superoxide $\left(\mathrm{O}_{2}^{-}\right)$converting $\mathrm{NO}$ to toxic peroxynitrite (ONOO-).

In addition to ONOO- formation, NO in conjunction with thiols and oxygen radicals generate nitrotyrosine and nitroarginine. Nitroarginine, in turn, competes for the substrate L-arginine of the eNOS reaction in a feedback mechanism, limiting further NO generation [44-46]. As a result, there is endothelial cell dysfunction, endothelial cell toxicity and endothelial cell loss-apoptosis, increased ROS, increased ONOO- and decreased NO associated with HHcy [47]. HHcy is multiplicative in nature and even though its effects may occur later in T2DM than the other associated A-FLIGHT substrate toxicities, it has a devastating - synergistic effect on endothelial cell function. Presently, we know there are other multiple metabolic toxicities (table 4 ) operating within the renal glomerulus producing microalbuminuria (reflecting endothelial cell 
dysfunction and damage) at a stage prior to the declining glomerular filtration rate responsible for HHcy (figure 2).

A recent clinical study by Maejima et al. [48] revealed significant elevated levels of ONOO- peroxynitrite (by Griess method) in 129 T2DM patients as compared to 76 nondiabetic controls. While there was no difference in basal plasma $\mathrm{NO}(2)(-)$ levels between the T2DM and control patients, ONOO- levels were related to the presence of hypertension and advanced microvascular complications. In addition, ONOO- correlated positively with elevations in AGEs and serum lipid peroxide. These data support the hypothesis that decreased endothelium-dependent vasodilatation in diabetic subjects is associated with the impaired action of NO secondary to its consumption (quenching) from redox stress rather than decreased NO production from vascular endothelium. Clinically, abnormal NO metabolism is related to advanced diabetic microvascular complications.

Zhang et al. [49] were able to demonstrate that increased concentrations of Hcy resulted in a decreased $\mathrm{NO}$ response to bradykinin and L-arginine. Hcy stimulated the formation of superoxide anions and peroxynitrite with increased levels of nitrotyrosine. The addition of 5methyltetrahydrofolate (folic acid) restored NO responses to bradykinin and L-arginine agonists. In addition, scavengers of peroxynitrite and SOD mimetics reversed the Hcy-induced suppression of NO production by endothelial cells. Concentrations of Hcy (greater than 20 micromolar concentration) produced a significant indirect suppression of eNOS activity without any discernible effects on its expression.

Li et al. just published an article showing an unexpected effect of Hcy-induced oxidative stress resulting in an increase of 3-hydroxy-3-methylglutaryl coenzyme A reductase in vascular endothelial cells, as well as decreasing endothelial NO. They were also able to demonstrate that "statins" increased NO as well as decreasing cellular cholesterol [50].

Stuhlinger et al were able to demonstrate that Hcy impairs the nitric oxide synthase pathway. Homocysteine inhibits dimethylarginine dimethylaminohydrolase (DDAH), which is responsible for degrading ADMA. This effect of Hcy causes the endogenous inhibitor of nitric oxide synthase, ADMA, to accumulate and compete with L-arginine for nitric oxide production. This effect helps to explain the deleterious effect of Hcy on the endothelial cells ability to promote vasodilatation and associated endothelial cell dysfunction with decreased NO synthesis [51].

Previous publications have emphasized the importance of the eNOS enzyme and the important role of the $\mathrm{Glu}^{298} \rightarrow$
Asp gene polymorphism [32,52]. Noiri and colleagues have recently demonstrated that the gene polymorphism (Glu ${ }^{298} \rightarrow$ Asp) affecting the eNOS enzyme is statistically and significantly associated with diabetic nephropathy in T2DM patients [53]. This finding points to the important role of the eNOS enzyme and eNO in controlling oxidative - redox stress and its relation to the development of diabetic nephropathy.

This same gene polymorphism (Glu298 $\rightarrow$ Asp) of the eNOS enzyme (eNOS 894TT genotype) has also been recently demonstrated to be a risk factor for HHcy. These findings by Brown et al. indicate that the NOS3 894TT genotype (eNOS Glu298 $\rightarrow$ Asp gene polymorphism) is a risk factor for HHcy in healthy nonsmoking adults with low serum folate and supports the hypothesis that nitric oxide modulates Hcy through an effect on folate catabolism [54].

\section{Accelerated atherosclerosis $\rightarrow$ atheroscleropathy}

The above discussion also applies to the accelerated atherosclerosis (atheroscleropathy) and intimal redox stress and remodeling (intimopathy) associated with MS, PD, and overt T2DM [32].

Insulin resistance is central to the development of CHD and the accelerated atheroscleropathy associated with MS, $\mathrm{PD}$, and overt T2DM. This being said, the ultimate manifestation of insulin resistance is T2DM [32] (figure 3).

Atherosclerosis, MS, PD, and T2DM present a pleiotropic mechanistic progression, in which, inflammation and upstream oxidative-redox stress and ROS appear to share a common - fertile soil background, and patients with diabetes experience both a preexisting and parallel-accelerated atherosclerosis, we have termed atheroscleropathy $[32,52,55]$ (figure 4).

In regards to silent coronary artery disease (CAD), Gazzaruso $\mathrm{C}$ et al. were able to confirm that microalbuminuria and smoking may predict silent CAD in people with diabetes and additionally they were able to demonstrate an original finding of an independent association between HHcy and silent CAD [56].

In the Framingham offspring study [57], those with hyperinsulinemia had significantly higher Hcy levels than those without, and subjects with more than two MS phenotypes (hypertension, impaired glucose tolerance, or a central MS [consisting of two or more of the following: hyperinsulinemia, obesity, or dyslipidemia]) had significantly higher Hcy levels compared to those with one or no MS phenotype. 


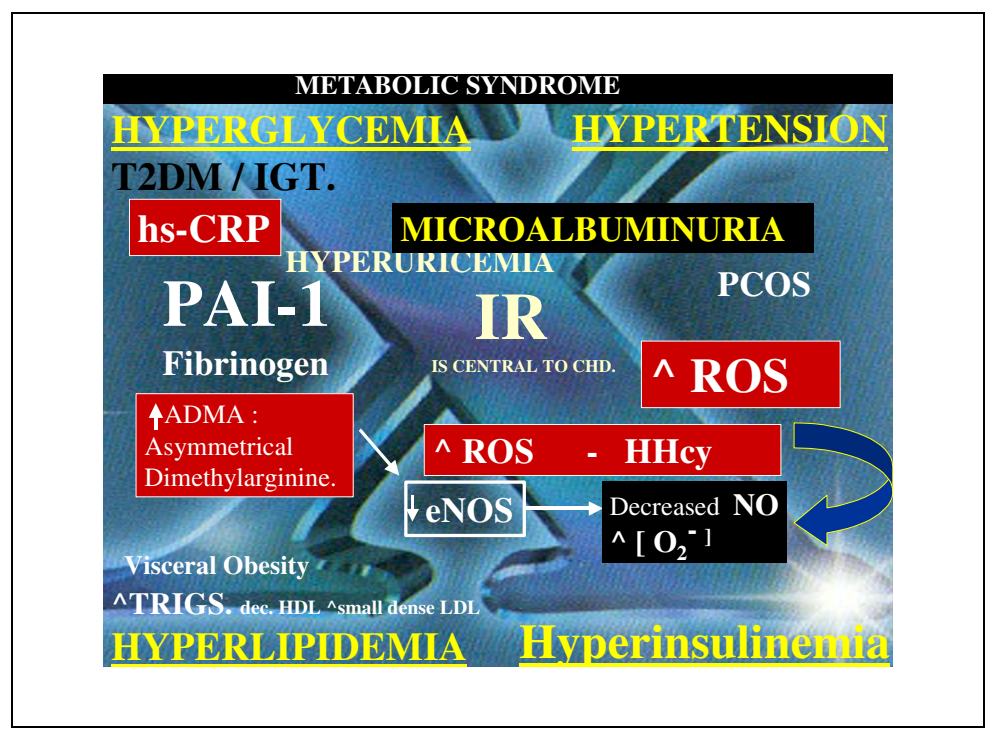

\section{Figure 3}

The metabolic syndrome: Syndrome X "reloaded" Metabolic syndrome (Syndrome X "reloaded") is a unique clustering of clinical syndromes and metabolic derangements. Reaven initially described the MS in 1988. He initially discussed the four major determinants consisting of: I. Hypertension. II. Hyperinsulinemia. III. Hyperlipidemia (Dyslipidemia of elevated VLDL triglycerides, decreased HDL-cholesterol, and elevated small dense atherogenic LDL-cholesterol). IV. Hyperglycemia or glucose intolerance. He also emphasized the importance of insulin resistance being central to the development of coronary artery disease or CHD. Since that time numerous papers and authors have added several associated findings to the MS and additionally several other names have been given to describe this clustering phenomenon. The important association of polycystic ovary syndrome (PCOS), hyperuricemia, fibrinogen, hsCRP, microalbuminuria, PAI-I, and the more recently added asymmetrical dimethyl arginine (ADMA), reactive oxygen species (ROS) and now the damaging oxidative potential of Hcy and endothelial dysfunction have all contributed to a better understanding of this complicated clustering phenomenon. The red boxes (ROS, Hcy, ADMA, and hsCRP) indicate the newer additions giving rise to the new terminology: Metabolic Syndrome Reloaded.

Passaro and colleagues have been able to demonstrate in T2DM patients that Hcy levels are influenced by both the duration of the disease and metabolic control. Hcy levels improve with improvement of glycemic control of HbA1c. Hcy remained strongly associated to the presence of CHD independent from age, sex, body mass index, smoking status, hypertension and lipid patterns. Additionally, they conclude that Hcy can be seen as a major risk factor in T2DM patients with CHD [58,59].

The initial vascular lesions described by McCully in 1969 [2] described an arteriosclerotic fibrotic change within the intima, which is in contrast to the intimal fibrous-lipid laden lesions associated with atherosclerosis and the vulnerable thin-cap fibroatheroma prone to rupture.
Burke and colleagues have been the first to describe the plaque morphology and correlate these findings to total plasma homocysteine [60]. Their recent publication demonstrated that Hcy is elevated in sudden unexpected death in men as a result of severe coronary artery disease without acute or organized coronary thrombosis. Additionally, they were able to demonstrate that the above association seemed to be increased if there existed concomitant diabetes mellitus. HHcy was associated with an increase in fibrous plaques and a relative decrease in thincap atheromas. Their findings suggest a different mechanism of atherogenesis from that of hypercholesterolemia. Additionally, efforts to reduce Hcy could be complementary to lipid lowering therapy because plaque fibrosis may occur via a distinct mechanism. They suggest that one 


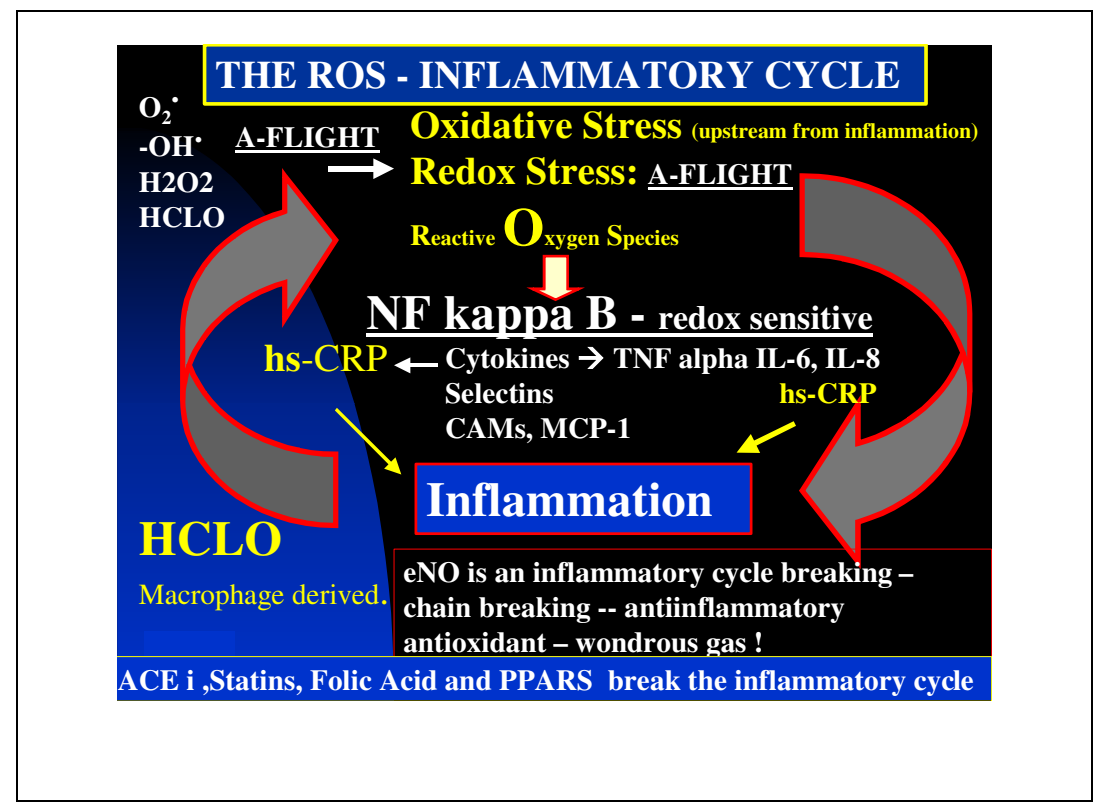

\section{Figure 4}

The reactive oxygen species - inflammatory cycle: ROS are upstream from the inflammatory cycle Inflammation in MS, PD, overt T2DM, and atheroscleropathy has recently emerged as an important factor. While it has been interesting to observe the development of this exciting story, it is important to remember that reactive oxygen species (ROS) cycle occurs upstream from the inflammatory cycle via the redox sensitive nuclear transcription factor: NF kappa B and the resulting inflammatory markers: Selectins, cellular adhesion molecules, monocyte chemoattractant protein - I, and the cytokines: TNF alpha, IL-6, IL-8 and the newer clinical laboratory tool of the highly sensitive C-reactive protein (hsCRP).

such mechanism could be endothelial dysfunction, which certainly points to the importance of the "Folate Shuttle phenomenon" within the endothelial cell and a relative endogenous endothelial folate deficiency within the endothelial microenvironment milieu.

These morphological findings suggest the need for; and importance of; global risk reduction of the entire spectrum of elevated substrates within the A-FLIGHT multiple metabolic toxicities.

\section{PPAR and homocysteine}

Peroxisome proliferator activated receptors (PPARs) are transcription factors belonging to the nuclear receptor super-family and the multiple roles of their effects are rapidly unfolding.
Clinically there are two classes of drugs currently in use: fibrates binding to PPAR alpha (gemfibrozil and fenofibrate) and thiazolidinediones (TZDs) binding primarily to PPAR gamma (rosiglitazone and pioglitazone). PPAR alpha agonists are responsible primarily for their hypolipidemic effect, while PPAR gamma agonists are antidiabetic agents - insulin sensitizers (enhancing insulin mediated glucose uptake and lowering of $\mathrm{HbA}_{1 \mathrm{C}}$ ), important in the regulation of the lipid metabolism and adipogenesis, and additionally expressed in the vasculature (endothelial cells, smooth muscle cells, and monocyte macrophage cells). In vitro and clinical data show that TZDs can decrease thrombotic, inflammatory, and oxidative changes that contribute to endothelial dysfunction and their future vaculoprotective roles (table 8) in attenuating the progressive role of non-diabetic atherosclerosis 
Table 8: POSITIVE EFFECTS OF PPARalpha AND PPARgamma AGONISTS

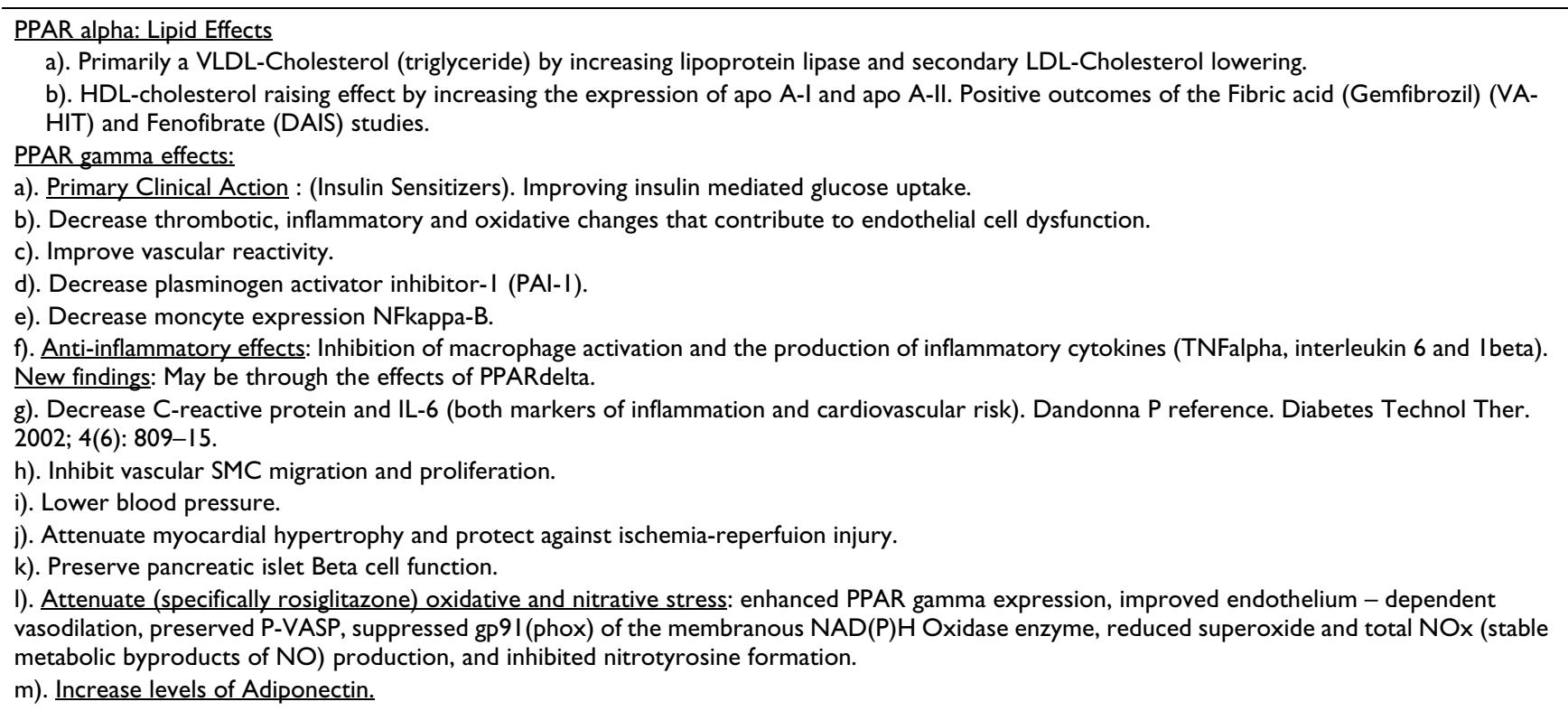

and the accelerated atherosclerosis in MS, PD, and overt T2DM [61-67].

Current available information suggests that PPAR-gamma ligands may prevent the progression of insulin resistance (preserving islet Beta cell function) to diabetes and endothelial dysfunction to atherosclerosis [68].

Recently, Fonseca V. et al. were able to demonstrate that the PPAR agonist troglitazone had a significant Hcy lowering effect in both the lean and fatty Zucker rat model of insulin resistance. This decline in Hcy was associated with significant increases in hepatic concentrations of S-adenosylhomocysteine (SAH) and S-adenosylmethionine (SAM) plus SAH. Additionally, there was a significant decline in the SAM/SAH ratio. The hepatic CBS was significantly higher in the troglitazone treated group as compared to the control group. The authors conclude that the Hcy lowering effect of troglitazone may be due to a shift in the concentrations of Hcy from the blood to the liver, as well as, a possible upregulation of hepatic CBS [69].

Tao et al. just published a timely article that ties together quite nicely the detrimental role of oxidative-redox stress and ROS and the antioxidant, antinitrative, and vasculoprotective role of PPARs. They were able to demonstrate (in hypercholesterolemic rabbits) that treatment with the PPAR gamma agonist rosiglitazone enhanced PPARgamma expression, improved endothelium-dependent vasodilatation, preserved the phosphorylation of vasodilator-stimulated phosphoprotein (P-VASP), suppressed gp91(phox) of the NAD(P)H Oxidase enzyme and iNOS expression, reduced superoxide and total NOx production, and inhibited nitrotyrosine formation [70]. Even though Hcy levels were not part of this publication, a reasonable assumption would be that rosiglitazone could also lower Hcy levels.

Recently, we have been able to demonstrate an important finding regarding the interactions of Hcy with PPAR alpha and gamma receptors. In addition to demonstrating that HHcy decreases bioavailability of eNO, generates nitrotyrosine, and activates latent matrix metalloproteinase (which instigates endomyocardial endothelial fibrosis and dysfunction) in vivo, we have been able to demonstrate that Hcy acts in a competitive manner with the PPAR receptor (in endomyocardial endothelial cells of mouse myocardium) in vitro. Specifically, Hcy interacts with the fibric acid PPAR alpha agonist ciprofibrate and the PPAR gamma agonist 15-deoxy-Delta(12,14)-prostaglandin $\mathrm{J}(2)$ (15d-PGJ 2 ) [71-74].

This may have definite clinical applications regarding the actions of the PPAR agonist family of fibric acid, as well as the PPAR agonists: TDZs (rosiglitazone and pioglitazone currently in clinical use). If Hcy is elevated there may exist a competitive inhibition of the agonist effects of both of these clinically useful medications (figure 5).

These findings of the potential interaction of Hcy with the PPAR ligands may interfere with the positive role of glucose -lipid regulation and anti-inflammatory 


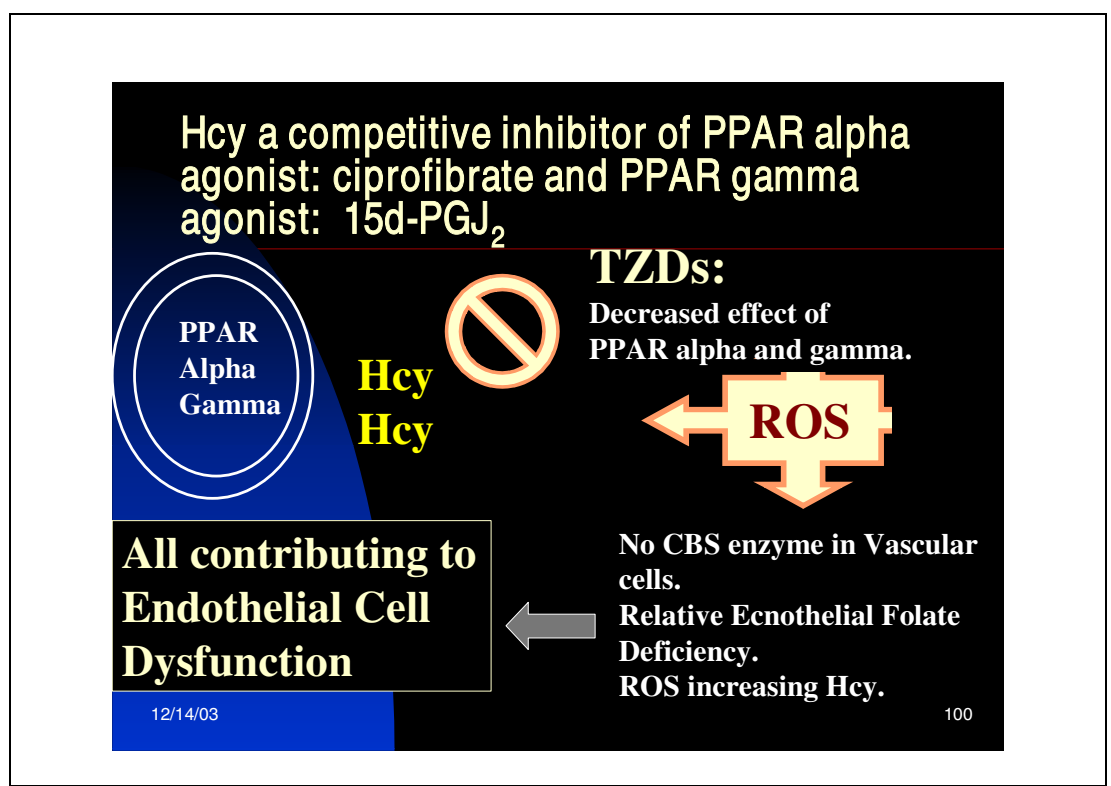

\section{Figure 5}

Homocysteine is a competitive inhibitor of PPAR agonists Hcy has recently been found to be a competitive inhibitor of the nuclear transcription factors: Peroxisome proliferator activated receptors (PPARs) alpha and gamma. Hcy acts as a ligand for the PPAR receptors alpha and gamma and therefore competes with the PPAR alpha ligand: ciprofibrate and the PPAR gamma ligand: I5-deoxy-Delta(I2, I4)-prostaglandin J(2) $(I 5 d-P G J)$. These findings have definite clinical applications, in that; if Hcy is not treated to optimal goals the thiazolidinediones (TZDs) may not have their maximal effect on the PPAR receptor.

antiatherosclerotic actions of the fibric acid derivatives and thiazolidinediones.

\section{Homocysteine - folate - cobalamin triad and atherogenesis}

Flynn MA et al. have discussed atherogenesis and the Homocysteine-Folate-Cobalamin (HFC) Triad and it seems pertinent to expand each of their respective roles in this discussion [75].

The toxic role of Hcy on the vasculature has been extensively discussed previously, however, the important role of folic acid and cobalamin (vitamin $\mathrm{B}_{12}$ ) needs further development.
Folic acid and the folate shuttle

Folic acid, the water soluble B vitamin (Vitamin $\mathrm{B}_{9}$ ), 5methyltetrahydrofolate (5-MTHF), has been recently gaining considerable attention due to its positive role in cardiovascular disease, neurodegenerative disorders, neural tube defects, and cancer. Folic acid plays an important role in the remethylation (methionine - folate cycle) of homocysteine and is thus capable of lowering elevated levels of homocysteine [76].

Deficiency or impairment of folate metabolism is associated with HHcy, hypomethylation (the decreased one carbon unit transfer to purines and pyrimidines for DNA repair and biosynthesis), DNA damage, and impaired cell proliferation, malignancies, and impaired eNO production $[47,77-80]$. 
5-MTHF is an electron donor, a hydrogen donor, and a methyl donor [52] and this attribute confers a unique role to its function. In regards to the eNOS reaction, it supplies both hydrogen and electrons to the oxidatively modified tetrahydrobiopterin (BH4): $\mathrm{BH} 2$ and $\mathrm{BH} 3$. Once biopterin is completely reduced to BH4 (the necessary cofactor for the eNOS reaction), the eNOS reaction can re-couple and restore the capability of this reaction to be once again a net producer of eNO instead of superoxide. This unique function of folic acid can restore endothelial dependent vasodilatation in T2DM and hyperlipidemia [81].

Folic acid supplementation would supply the methyl donating substrate to run the methionine-folate cycle, as well as, supply the hydrogen and electrons to stabilize the requisite $\mathrm{BH} 4$ cofactor to run the eNOS reaction resulting in the production of eNO by the endothelium. The restoration of the eNOS reaction, by folate supplementation, has been demonstrated acutely by flow mediated dilation studies in T2DM and coronary artery disease via mechanisms, which are largely independent of Hcy lowering $[82,83]$.

We hypothesize that there may exist a folate shuttle, which is operative in the atheroscleropathy associated with MS, PD, and T2DM, as well as, non-diabetic atherosclerosis. This folate shuttle effect may operate as an effective mechanism in the endothelial microenvironment to recouple the oxidatively stressed, uncoupled, and dysfunctional eNOS reaction (figures 1).

There are three critical arms associated with the eNOS reaction: the eNOS enzyme, the L-arginine substrate, and the BH4 cofactor. Each of these three arms is crucial and has been discussed in previous publications $[31,32,52,84]$. The eNOS reaction may be uncoupled due to oxidative-redox stress associated with MS, PD, T2DM, atheroscleropathy, and non-diabetic atherosclerosis. When the eNOS reaction is uncoupled the reaction will become a net producer of superoxide (instead of eNO via the eNOS reaction) through the reaction of membranous $\mathrm{NAD}(\mathrm{P}) \mathrm{H}$, oxygen, and the $\mathrm{NAD}(\mathrm{P}) \mathrm{H}$ Oxidase enzyme (figure 6).

The following eNOS reaction demonstrates the location of the vulnerable three arms of the eNOS reaction responsible for the generation of eNO (figure 6).

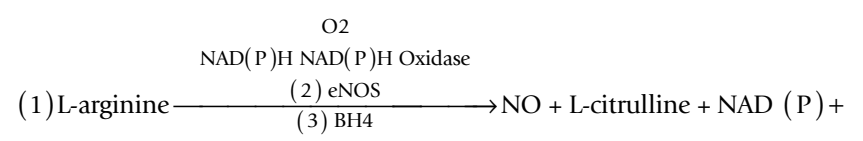

If the eNOS reaction is uncoupled: there is the net production of superoxide instead of eNO.

$$
\mathrm{NAD}(\mathrm{P}) \mathrm{H} \stackrel{\mathrm{O} 2}{\mathrm{NAD}(\mathrm{P}) \mathrm{H} \text { Oxidase }} \mathrm{NAD}(\mathrm{P})++\underline{\mathrm{O} 2^{\prime}}
$$

The healthy endothelium is a net producer of endothelial nitric oxide [eNO].

The activated - dysfunctional - uncoupled endothelium is a net producer of superoxide $\left[\mathrm{O}_{2}{ }^{\circ}\right]$ associated with MS, PD, T2DM, and atheroscleropathy.

The net production of superoxide by the uncoupled eNOS reaction in addition to the production of ROS via the AFLIGHT metabolic toxicities results in an excessive oxidative-redox stress.

This oxidant stress may contribute to the oxidation of $\mathrm{BH} 4$ to $\mathrm{BH} 2$ and $\mathrm{BH} 3$, which will be unable to run the eNOS reaction. Folate supplementation as a methyl donor, a hydrogen donor, and an electron donor may restore the oxidized $\mathrm{BH} 2$ and $\mathrm{BH} 3$ to the requisite completely reduced $\mathrm{BH} 4$ by donating hydrogen and an electron to $\mathrm{BH} 2$ and $\mathrm{BH} 3$. With the restoration of $\mathrm{BH} 4$, the eNOS reaction may recouple and once again run the eNOS reaction in order be a net producer of eNO.

As folate is being shared, stolen, shunted, or shuttled from the remethylation methionine-folate cycle to the eNOS reaction there will develop a relative endogenous endothelial folate deficiency with ensuing intra endothelial Hcy accumulation.

The HHcy that results will then play its own additive autooxidative role in the continuing viscous cycle of oxidative stress to the endothelial microenvironment discussed previously.

If this endothelial folate shuttle does exist, then one might assume that Hcy could be a marker of underlying endothelial oxidative - redox stress in addition to being a risk factor. The importance of HHcy being a dual risk (a risk marker and a risk factor) in this patient population certainly points to its importance in being both a result of oxidative -redox stress and its important causative role in endothelial dysfunction.

The importance of the endothelial cell lacking the CBS enzyme only contributes to the hypothesis of an endothelial folate shuttle. Even if measured plasma folate and Hcy levels are normal there may exist a relative endogenous endothelial folate deficiency within the endothelial microenvironment due to the folate shuttle phenomenon. 


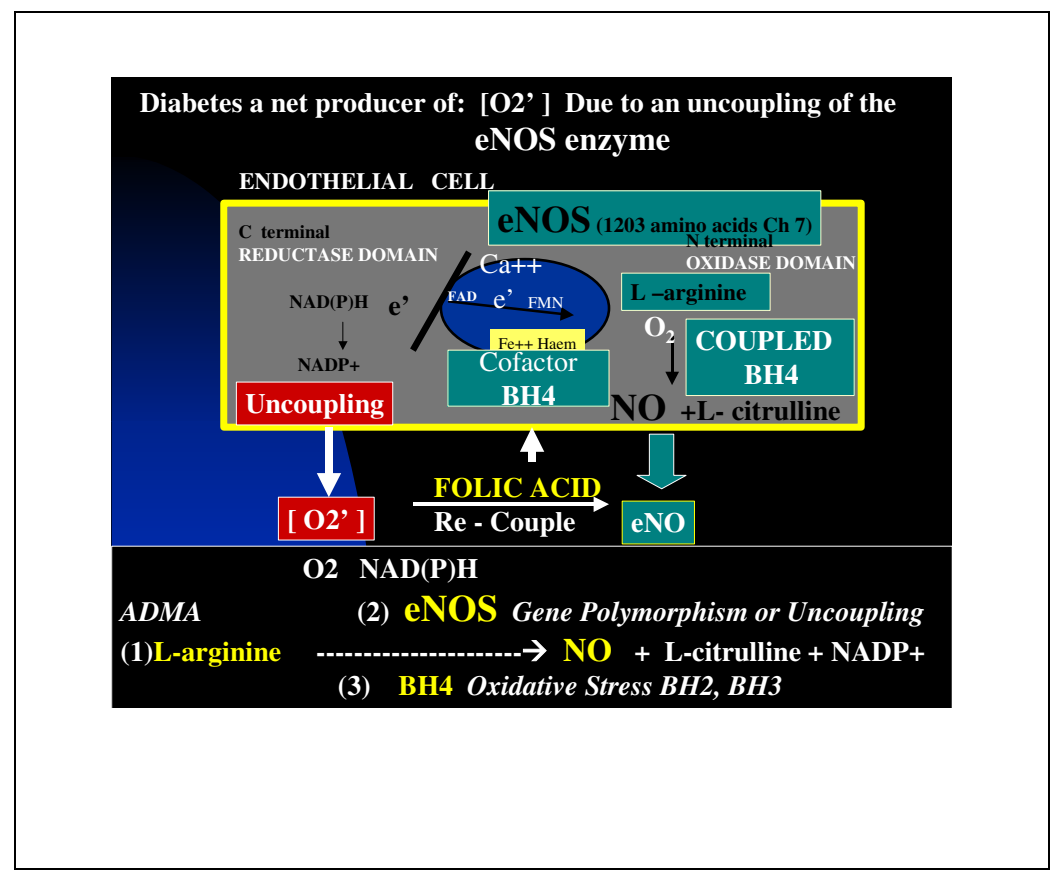

\section{Figure 6}

Uncoupling of the eNOS reaction This figure demonstrates the three vulnerable arms of the plasma membrane bound eNOS reaction responsible for the production of the omnipotent endothelial nitric oxide. Oxygen reacts with the eNOS enzyme in which the essential $\mathrm{BH} 4$ cofactor has coupled $\mathrm{NAD}(\mathrm{P}) \mathrm{H}$ with $\mathrm{L}$-arginine to be converted to eNO and $\mathrm{L}$-citrulline. If uncoupled due to oxidative - redox stress with the essential $\mathrm{BH} 4$ cofactor now in the $\mathrm{BH} 2$ or $\mathrm{BH} 3$ oxidized state the reaction will become one of superoxide production adding to the oxidative - redox stress within the endothelial microenvironment. The healthy endothelium is a net producer of eNO, whereas, the dysfunctional endothelium becomes a net producer of superoxide. It is in this situation that the stabilization of the essential $\mathrm{BH} 4$ cofactor (preventing oxidation to $\mathrm{BH} 4$ ) by adequate supplementation of folate becomes so very important.

\section{Cobalamin (vitamin $B_{12}$ )}

HHcy is a sensitive marker of clinical cobalamin (the water soluble vitamin $\mathrm{B}_{12}$ ) deficiency $[85,86]$. Folate fortification as well as a more widespread use of folate supplements will have an effect in reducing the frequency of folate deficiency and cobalamin deficiency may be ranked above folate deficiency as a primary modifiable cause of HHcy [87-89].

Common causes of cobalamin deficiency are malabsorption as a result of (i). lack or dysfunction of gastric intrinsic factor (ii). hypochlorhydria as a result of chronic gastritis, gastric atrophy, or the use of proton pump inhibitors (iii). the clinical syndromes of inflammatory bowel disease and celiac disease.

It is of interest to note that one of our newer medications in our treatment armamentarium for MS, PD, and T2DM is emerging as a common cause of cobalamin malabsorption. Metformin use has recently skyrocketed as a popular treatment for the metabolic derangements associated with MS, PD, and T2DM. This more novel, yet increasingly, common cause of cobalamin deficiency in adults and teenager necessitates a careful approach for the clinician. Currently, in patients with vitamin B12 deficiency or evidence of peripheral neuropathy or macrocytic anemia the use of metformin should always be considered in the dif- 
ferential diagnosis of B12 malabsorption [90]. A strong consideration for patient screening of megaloblastic anemia and or B12 levels in patients on long-term use of metformin should be considered [91].

Folate fortification and supplementation may mask the megaloblastic anemia associated with cobalamin deficiency, while allowing the neurological manifestations of pernicious anemia (peripheral neuropathy, cognitive disturbances, dementia, and depression) to progress. Therefore it is imperative that cobalamin deficiency be aggressively sought out and treated, especially in the elderly. In the United States there are 37 million people over the age of 65 with conservative estimates indicating a two to three percent ( 1.1 million) prevalence either having or will develop pernicious anemia.

Additionally, there are estimated to be $20-30$ percent (7.4 - 11.1 million) of this population having subclinical cobalamin - B12 deficiency, which may lead to HHcy [87].

Flynn and colleagues [88] were able to demonstrate in their Longitudinal Aging Study [75] that $\mathrm{B}_{12}$ supplementation (100 microgram by mouth daily) was effective ( $P$ value 0.0067 ) in alleviating HHcy in those patients with a baseline B12 level $<350$.

In a meta-analysis of Hcy-lowering studies, folic acid by mouth (0.5-5 mg daily) resulted in a reduction of Hcy by $25 \%(\mathrm{P}<0.001)$. The addition of $0.5 \mathrm{mg}$ vitamin $\mathrm{B}_{12}$ by mouth daily reduced the Hcy levels by another 3\% to $10 \%$ over the reduction with folic acid alone. It was interesting to note that the addition of $16.5 \mathrm{mg}$ vitamin $\mathrm{B}_{6}$ daily produced no significant supplemental reducing effect on blood Hcy levels $[89,92,93]$.

\section{Conclusion}

The multiple metabolic A-FLIGHT toxicities (table 4) observed in MS, PD, T2DM, and atheroscleropathy are associated with an increase in ROS production. These ROS result in an increase in oxidative-redox stress and contribute to the uncoupling of the eNOS reaction and endothelial cell dysfunction.

When accessing the role of the dual risk of HHcy, one has to be aware of the synergistic effects of ROS produced by the other multiple toxicities of the A-FLIGHT acronym and their contributing role of oxidative-redox stress to the endothelium. This points to the important concept of global risk reduction when dealing with MS, PD, T2DM, and atheroscleropathy.

The current controversy of HHcy being a marker of risk or a risk factor (important in causation) is not as important as understanding its overall role in the association with endothelial cell damage, dysfunction, and a decrease in eNO bioavailability and how it interacts with other ROS.

The importance of a possible endothelial folate shuttle points to the important role of folate supplementation in these at risk patients in order to recouple the eNOS reaction and increase eNO production in addition to its remethylation properties in the methionine-folate cycle resulting in lowering of Hcy.

Recently we have become aware of the important role of highly sensitive $\mathrm{C}$ reactive protein (hsCRP) and the role of inflammation in the development and progression of cardiovascular disease, MS, PD, and T2DM [94-98]. It has been interesting to watch the hsCRP story unfold and since oxidative - redox stress occurs upstream from the inflammatory cycle via the activation of NFkappa B it seems so very important to better understand the role of HHcy and how it interacts with the ROS produced by the other metabolic toxicities of the A-FLIGHT acronym (figure 4).

Dietary folate supplementation is extremely important for proper endothelial cell health maintenance and function. A simplified overview of the positive roles of folate supplementation include the following [99]:

I. Folate is a methyl donor. Important in lowering the toxic Hcy elevation. Hcy elevation may be a marker of folate deficiency or dysfunction.

II. Folate is a hydrogen donor. Important in maintaining and stabilizing the essential tetrahydrobiopterin (BH4) Cofactor of the eNOS enzyme reaction to prevent uncoupling.

III. Folate is an electron donor. Important as an antioxidant to reduce oxidative - redox stress. Important as a chain breaking antioxidant. Stabilizing the eNOS reaction and protecting the generation of eNO.

Numbers II and III could be thought of as pleiotropic effects: The effects of folate supplementation independent of Hcy lowering, which play a significant role in the stabilization of the eNOS reaction and production of eNO as discussed in the section regarding the FOLATE SHUTTLE phenomenon.

Therefore, in addition to nutritional - dietary folate intake [100], pharmacological folate supplementation should now be strongly considered as part of the clinical global risk reduction treatment paradigm for those at risk patients with MS, PD, T2DM, and atheroscleropathy. 
R Reductase inhibitors (HMG-CoA). Decreasing modified LDL-cholesterol, i.e. oxidized, acetylated LDL-cholesterol. Decreasing triglycerides and increasing HDL-cholesterol Improving endothelial cell dysfunction. Restoring the abnormal Lipoprotein fractions. Thus, decreasing the redox and oxidative stress to the arterial vessel wall and myocardium. Redox stress reduction.

A Angll inhibition or blockade: ACEi-prils. ARBS-sartans. Both inhibiting the effect of angiotensin-II locally as well as systemically. Affecting hemodynamic stress through their antihypertensive effect as well as the deleterious effects of angiotensin II on cells at the local level - injurious stimuli -decreasing the stimulus for $\mathbf{O}_{2}{ }^{*}$ production. Decreasing the A-FLIGHT toxicities. Plus the direct-indirect antioxidant effect within the arterial vessel wall and capillary.

Antioxidant effects.

Aspirin antiplatelet, anti-inflammatory effect.

Adrenergic (non-selective blockade) in addition to its blockade of Prorenin $\rightarrow$ Renin

Amlodipine with its calcium channel blocking antihypertensive effect, in addition to its direct antioxidant effects. Redox stress reduction.

A Aggressive control of diabetes to $\mathrm{HbA}_{\mathrm{Ic}}$ of less than 7. (This usually requires combination therapy with the use of: Insulin secretagogues, insulin sensitizers (thiazolidinediones), biguanides, alpha-glucosidase inhibitors, and ultimately exogenous insulin.) [36-38]

Decreasing modified LDL cholesterol, i.e. glycated - glycoxidated LDL cholesterol. Improving endothelial cell dysfunction. Also decreasing glucotoxicity and the oxidative - redox stress to the intima and pancreatic islet.

Aggressive control of blood pressure, which usually requires combination therapy, including thiazide diuretics to attain JNC 7 guidelines. Aggressive control of Hcy with folic acid and its associated pleiotropic positive effect on re-coupling the eNOS reaction by restoring the activity of the $\mathrm{BH} 4$ cofactor to run the eNOS reaction and once again produce eNO, as well as, its direct antioxidant effects: $\mathrm{BH} 4$ and eNOS stabilization Redox stress reduction.

S Statins. Improving plaque stability (pleiotropic effects) independent of cholesterol lowering. Improving endothelial cell dysfunction. Plus, the direct - indirect antioxidant anti-inflammatory effects within the islet and the arterial vessel wall promoting stabilization of the unstable, vulnerable islet and the arterial vessel wall.

Style: Lifestyle modification: lose weight, exercise, and change eating habits. Stop Smoking Redox stress reduction

Controversy exists as to who should be screened and who should be treated. The following questions are appropriate:

Should we do not test and do not treat?

Should we treat all patients because it makes good clinical sense and therapy is inexpensive?

Should we screen patients with established atherosclerotic and venous thromboembolic disease and high-risk patients with MS, T2DM, and atheroscleropathy and initiate therapy if Hcy is at or above the 9-15 micromol/L range?

The later is preferred and it may be suggested that the current treatment guidelines for the treatment of HHcy should be one of cardiovascular global risk reduction (table 9) of oxidative - redox stress and reactive oxygen species generated from the multiple metabolic toxicities (table 4). In addition to global risk reduction, current suggested guidelines for the treatment of HHcy as a result of this review are presented in (table 10) [101].

The significance of proper nutrition is of paramount importance; however, once moderate to severe HHcy is identified, existing concepts indicate that diet alone is insufficient to normalize Hcy levels in many patients.
This brief review has attempted to provide the reader with a database of knowledge regarding the current role of Hcy and how it interacts with the MS, T2DM, and atheroscleropathy. For those interested in a more in depth review consideration should be given to review the new Journal: METABOLIC SYNDROME AND RELATED DISORDERS. Volume 1 number 2 has been dedicated to homocysteine and the metabolic syndrome [102-110].

Soinio $\mathrm{M}$ et al. have just published an exciting article involving a large cohort of patients (462 men and 368 women in the age group of 45-64 years of age at baseline) with T2DM. They were able to demonstrate that plasma Hcy was a strong and independent risk factor for CHD events. Even though impaired renal function is associated with higher plasma Hcy concentrations, this group was able to show that the association between elevated plasma Hcy level and high incidence of CHD events did not depend on renal function [111].

The damaging - toxic role of Hcy in the vascular bed has been well documented in the medical literature and its diffuse role not only in MS, T2DM, and atheroscleropathy but also in multiorgan damage is emerging [80] (figure 7).

To summarize, HHcy in the general population is an independent risk factor for cardiovascular disease as occurs in thrombotic events (such as arterial and venous occlusion) and ischemic disease such as stroke and myocardial infarction (two of the most common causes of death and dis- 
Table 10: SUGGESTEDTREATMENT GUIDELINES FOR HHcy

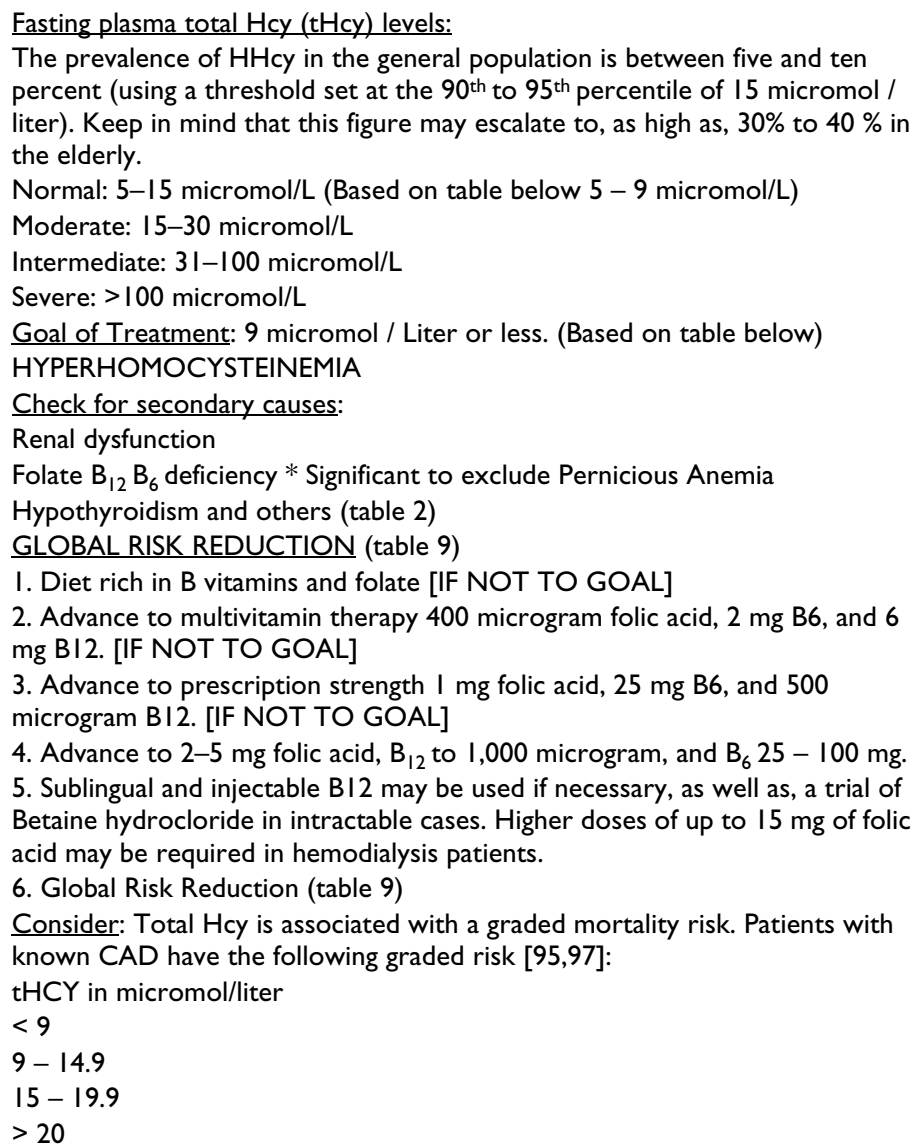

ability). With an aging population who are at greater risk of developing these morbid and mortal cardiovascular diseases associated with MS, T2DM, and atheroscleropathy, there should exist a dedicated consideration for folate and possible cobalamin supplementation, in addition too global risk reduction.

\section{Abbreviations}

Ang II: angiotensin II; RAAS renin angiotensin aldosterone system; ROS: reactive oxygen species $\left(\mathrm{O}_{2}{ }^{\bullet},-\mathrm{OH}^{\bullet}\right.$, $\mathrm{H}_{2} \mathrm{O}_{2}, 1 \mathrm{O}_{2}$ ); AT-1 angiotensin type one receptor; PKC: protein kinase C; IAPP: islet amyloid polypeptide; TGFbeta -1 : transforming growth factor beta- $1 ; \mathrm{NAD}(\mathrm{P}) \mathrm{H}$ oxidase: nicotine adenine di nucleotide phosphate oxidase reduced; AGE: advanced glycation endproducts; AFE: advanced fructosylation endproducts; RAGE: receptor for advanced glycosylation endproducts; ALE: advanced lipoxidation endproducts; eNOS: Endothelial Nitric Oxide Synthase; NO: nitric oxide; BH4: tetra hydro biopterin; FFA: free fatty acids; LC acyl -CoA's: long chain acyl Co enzyme A; VLDL: Very low density lipoprotein; LDL: low density lipoprotein; HDL: high density lipopro- tein; MS: Metabolic Syndrome; PD: prediabetes; T2DM: type 2 diabetes mellitus; PAI-1: plasminogen activator inhibitor $-1 ; \mathrm{H}_{2} \mathrm{O}$ : water; Glut-4: glucose transporter-4; PI3 Kinase: phosotidyl inositol 3 kinase; Akt: protein kinase B; MAP Kinase: mitogen activated protein Kinase; MAP Kinase Shunt: The shunting away from the positive Glut 4 PI3 Kinase Akt pathway to the deleterious MAP Kinase pathway promoting remodeling due to an alteration in the NO redox sensitive PI3 Kinase /Akt pathway; IL-6 IL-8: interleukin-6 interleukin-8; TNF alpha: tumor necrosis factor alpha; MPO: myeloperoxidase: Generation of Superoxide $\left(\mathrm{O}_{2}{ }^{\circ}\right)$ via hypochlorous acid $\mathrm{HClO} ; \mathrm{NF}$ kappa B: nuclear factor kappa B; ICAM: inter cellular adhesion molecule; VCAM: vascular cellular adhesion molecule; MCP-1: monocyte chemoattractant protein-1; NADH: nicotinamide adenine dinucleotide reduced; NAD+: nicotinamide adenine dinucleotide oxidized; DAG: diacylglycerol; GPx: glutathione peroxidase; DDAH: dimethylarginine dimethylaminohydrolase; ADMA: asymmetrical dimethyl arginine; $\mathrm{O}_{2}^{\bullet}-\mathrm{ONOO}^{\bullet}$ : superoxide - peroxynitrite. 


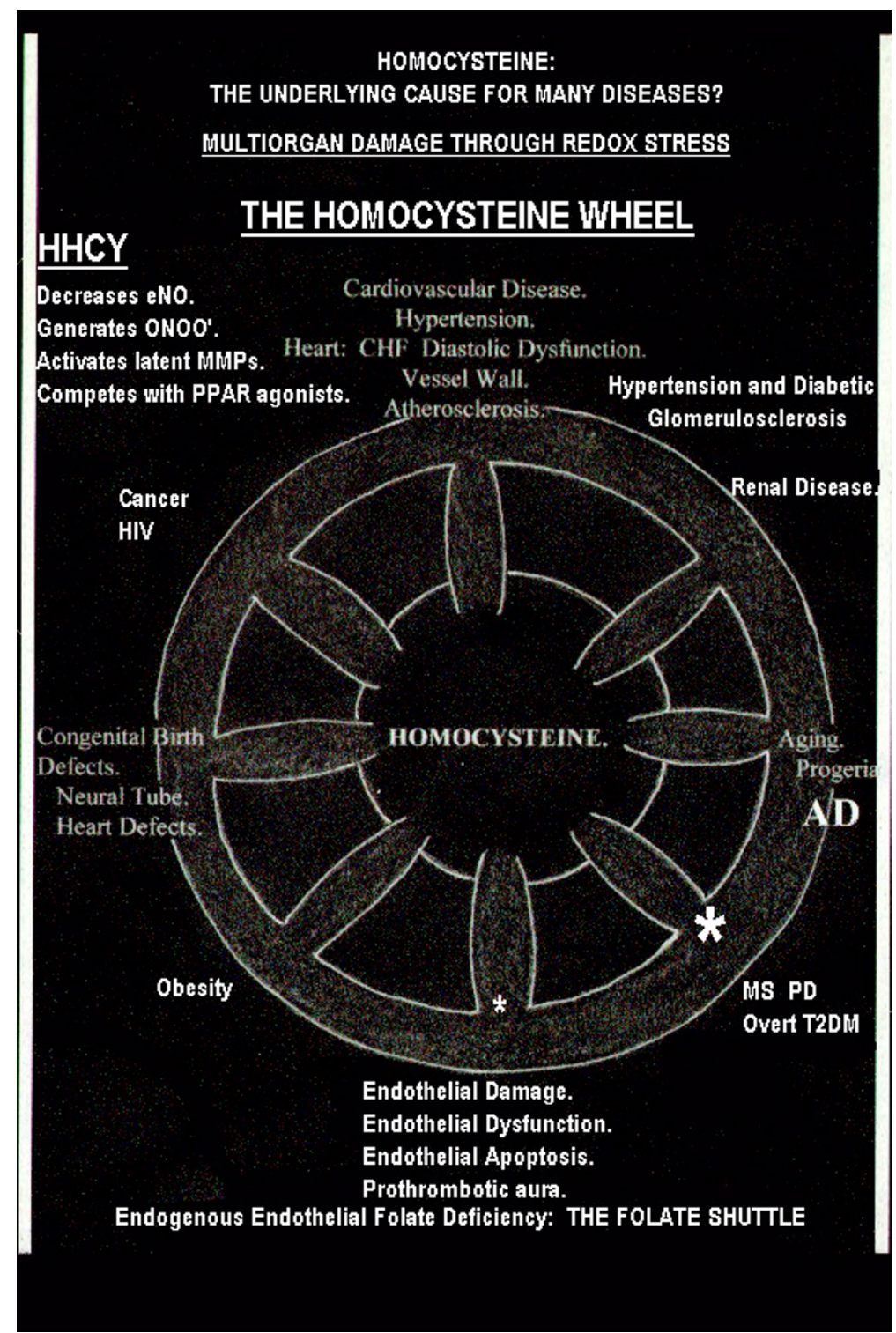

Figure 7

The homocysteine wheel: multiorgan damage through redox stress Homocysteine is capable of causing multi-organ damage through the process of oxidative - redox stress. The endothelium is very vulnerable to the effects of $\mathrm{HHcy}$ because the endothelium lacks the CBS enzyme, which results in the local loss of the important catabolic metabolism of Hcy. While this article has focused on the cardiovascular manifestations associated with MS, PD, and T2DM there exists numerous other organ systems and diseases associated with the damaging effects of HHcy.

\section{Competing interests}

None declared.

\section{Authors' contributions}

MRH and SCT contributed equally in the inception, writing, and editing of this manuscript. 


\section{Acknowledgements}

A part of this study was supported by $\mathrm{NIH}$ grants $\mathrm{HL}-7 \mathrm{I} 010$ and $\mathrm{HL}-74185$

This review is dedicated to: Margaret A Flynn PhD. (Professor Emeritus) Department of Family and Community Medicine, University of Missouri School of Medicine Columbia, Missouri for her dedicated work, body of nutritional research, and dedicated teaching of students in medicine.

\section{References}

I. DuVigneaud VE: A Trail of Research in Sulfur Chemistry. Ithaca, NY: Cornell University Press; 1952

2. McCully KS: Vascular pathology of homocysteinemia: implications for the pathogenesis of arteriosclerosis. Am J Pathol 1969, 56(I): III-I28.

3. Stampfer MJ, Malinow MR, Willett WC, Newcomer L, Upson B, Ullmann $\mathrm{D}$, Tishler $\mathrm{P}$, Hennekens $\mathrm{CH}$ : A prospective study of plasma homocyst(e)ine and risk of myocardial infarction in US physicians. JAMA 1992, 268:877-881.

4. Arnesen E, Refsum H, Bonaa KH, Ueland PM, Forde OH, Nordrehaug JE: Serum total homocysteine and coronary heart disease. Int J Epidemiol 1995, 24(4):704-709.

5. Boushey C], Beresford SA, Omenn GS, Motulsky AG: A quantitative assessment of plasma homocysteine as a risk factor for vascular disease. Probable benefits of increasing folic acid intakes. JAMA 1995, 274( I3): 1049-1057.

6. Graham IM, Daly LE, Refsum HM, Robinson K, Brattstrom LE, Ueland PM: Plasma homocysteine as a risk factor for vascular disease. The European Concerted Action Project. JAMA 1997, 277(22): $1775-178 \mid$

7. Wald NJ, Watt HC, Law MR, Weir DG, McPartlin J, Scott JM: Homocysteine and ischemic heart disease: results of a prospective study with implications regarding prevention. Arch Intern Med 1998, I 58(8):862-867.

8. Hoogeveen EK, Kostense PJ, Beks PJ, Mackaay AJ, Jakobs C, Bouter LM, Heine RJ, Stehouwer CD: Hyperhomocysteinemia is associated with an increased risk of cardiovascular disease, especially in non-insulin-dependent diabetes mellitus: a population-based study. Arterioscler Thromb Vasc Biol 1998, 18(I): 133-138.

9. Welch GN, Loscalzo J: Homocysteine and atherothrombosis. $N$ Engl J Med I 998, 338( I 5): 1042-50.

10. Stehouwer CD, Weijenberg MP, van den Berg M, Jakobs C, Feskens EJ, Kromhout D: Serum homocysteine and risk of coronary heart disease and cerebrovascular disease in elderly men: a 10-year follow-up. Arterioscler Thromb Vasc Biol 1998, 18(12): I895-1901.

II. Kark JD, Selhub J, Adler B, Gofin J, Abramson JH, Friedman G, Rosenberg IH: Nonfasting plasma total homocysteine level and mortality in middle-aged and elderly men and women in Jerusalem. Ann Intern Med 1999, I 3 I(5):32 I-330.

12. Hoogeveen EK, Kostense PJ, Jakobs C, Dekker JM, Nijpels G, Heine RJ, Bouter LM, Stehouwer CD: Hyperhomocysteinemia increases risk of death, especially in type 2 diabetes : 5 -year follow-up of the Hoorn Study. Circulation 2000, I0I(13): I506-15II.

13. Boers $\mathrm{GH}$ : Mild hyperhomocysteinemia is an independent risk factor of arterial vascular disease. Semin Thromb Hemost 2000, 26(3):29|-295.

14. Blom HJ: Consequences of homocysteine export and oxidation in the vascular system. Semin Thromb Hemost 2000, 26(3):227-232.

15. Jakubowski H, Zhang L, Bardeguez A, Aviv A: Homocysteine thiolactone and protein homocysteinylation in human endothelial cells: implications for atherosclerosis. Circ Res 2000, 87(I):45-5I.

16. Misra HP: Generation of superoxide free radical during the autoxidation of thiols. J Biol Chem I974, 249(7):2I5I-2I 55.

17. Jakubowski $\mathrm{H}$ : Homocysteine is a protein amino acid in humans. Implications for homocysteine-linked disease. J Biol Chem 2002, 277(34):30425-3048.

18. Schnyder G, Roffi M, Pin R, Flammer Y, Lange H, Eberli FR, Meier B, Turi ZG, Hess OM: Decreased rate of coronary restenosis after lowering of plasma homocysteine levels. $N$ Engl J Med 200I, 345(22): 1593-1600.
19. Schnyder G, Roffi M, Flammer Y, Pin R, Hess OM: Effect of homocysteine-lowering therapy with folic acid, vitamin B 12 , and vitamin B6 on clinical outcome after percutaneous coronary intervention: the Swiss Heart study: a randomized controlled trial. JAMA 2002, 288(8):973-979.

20. Schnyder G, Rouvinez G: Total plasma homocysteine and restenosis after percutaneous coronary angioplasty: current evidence. Ann Med 2003, 35(3): I56-163.

21. Hodish I, Matetzky S, Sela BA, Guetta V, Goldenberg I, Doolman R, Freimark D, Hod H, Selah BA: Effect of elevated homocysteine levels on clinical restenosis following percutaneous coronary intervention. Cardiology 2002, 97(4):2 I 4-2I7.

22. Mahanonda N, Leowattana W, Kangkagate C, Lolekha P, Pokum S: Homocysteine and restenosis after percutaneous coronary intervention. I Med Assoc Thai 200I, 84(Suppl 3):S636-644.

23. Genser D, Prachar H, Hauer R, Halbmayer WM, Mlczoch J, Elmadfa I: Relation of homocysteine, vitamin B(I 2), and folate to coronary in-stent restenosis. Am J Cardiol 2002, 89(5):495-499.

24. Liem A, Reynierse-Buitenwerf GH, Zwinderman AH, Jukema JW, van Veldhuisen DJ: Secondary prevention with folic acid: effects on clinical outcomes. J Am Coll Cardiol 2003, 4 I ( I 2):2 I05-2 I I3.

25. Guilland JC, Favier A, Potier de Courcy G, Galan P, Hercberg S: Hyperhomocysteinemia: an independent risk factor or a simple marker of vascular disease? I. Basic data. Pathol Biol (Paris) 2003, 5 I (2): I0I-II0.

26. Guilland JC, Favier A, Potier de Courcy G, Galan P, Hercberg S: Hyperhomocysteinemia: an independent risk factor or a simple marker of vascular disease? 2. Epidemiological data. Pathol Biol (Paris) 2003, 5 I (2): I I I-I2I.

27. Finkelstein JD: The metabolism of homocysteine: pathways and regulation. Eur J Pediatr 1998, 157(Suppl 2):S40-44.

28. Finkelstein JD: Methionine metabolism in mammals. J Nutr Biochem 1990, I:228-237.

29. Hoogeveen EK, Kostense PJ, Jakobs C, Dekker JM, Nijpels G, Heine RJ, Bouter LM, Stehouwer CD: Hyperhomocysteinemia increases risk of death, especially in type 2 diabetes: 5-year follow-up of the Hoorn Study. Circulation 2000, IOI(13): I506-I5II.

30. Hoogeveen EK, Kostense PJ, Beks PJ, Mackaay AJ, Jakobs C, Bouter LM, Heine RJ, Stehouwer CD: Hyperhomocysteinemia is associated with an increased risk of cardiovascular disease, especially in non-insulin-dependent diabetes mellitus: a population-based study. Arterioscler Thromb Vasc Biol 1998, 18(I): I33-138.

31. Hayden MR, Tyagi SC: Islet redox stress: the manifold toxicities of insulin resistance, metabolic syndrome and amylin derived islet amyloid in type 2 diabetes mellitus. JOP 2002, 3(4):86- 108.

32. Hayden MR, Tyagi SC: Intimal redox stress: Accelerated atherosclerosis in metabolic syndrome and type 2 diabetes mellitus. Atheroscleropathy. Cardiovasc Diabetol 2002, I (I):3.

33. Jacques PF, Bostom AG, Williams RR, Ellison RC, Eckfeldt JH, Rosenberg IHk, Selhub J, Rozen R: Relation between folate status, a common mutation in methylenetetrahydrofolate reductase, and plasma homocysteine concentrations. Circulation 1996, 93:7-9.

34. Arruda VR, von Zuben PM, Chiaparini LC, Annichino-Bizzacchi JM, Costa FF: The mutation Ala677 $\rightarrow$ Val in the methylene tetrahydrofolate reductase gene: a risk factor for arterial disease and venous thrombosis. Thromb Haemost 1997, 77:818-82I.

35. Feix A, Fritsche-Polanz R, Kletzmayr J, Vychytil A, Horl WH, SunderPlassmann G, Fodinger M: Increased prevalence of combined MTR and MTHFR genotypes among individuals with severely elevated total homocysteine plasma levels. Am J Kidney Dis 200I, 38:956-964.

36. Woo KS, Chook P, Lolin YI, Sanderson JE, Metreweli C, Celermajer DS: Folic acid improves arterial endothelial function in adults with hyperhomocystinemia. J Am Coll Cardiol 1999, 34:2002-2006.

37. Audelin MC, Genest J Jr: Homocysteine and cardiovascular disease in diabetes mellitus. Atherosclerosis 200I, 159:497-5 I I.

38. Rosolova H, Simon J, Mayer O Jr, Racek J, Dierze T, Jacobsen DW: Unexpected inverse relationship between insulin resistance and serum homocysteine in healthy subjects. Physiol Res 2002, $5 I(1): 93-98$.

39. Hiragushi K, Sugimoto H, Shikata K, Yamashita T, Miyatake N, Shikata Y, Wada J, Kumagai I, Fukushima M, Makino H: Nitric oxide system 
is involved in glomerular hyperfiltration in Japanese normoand micro-albuminuric patients with type $\mathbf{2}$ diabetes. Diabetes Res Clin Pract 200I, 53(3): I49-I59.

40. Henegar JR, Bigler SA, Henegar LK, Tyagi SC, Hall JE: Functional and structural changes in the kidney in the early stages of obesity. J Am Soc Nephrol 2001, I 2(6): I2I I-I 217.

4I. Apakkan Aksun S, Ozmen B, Ozmen D, Parildar Z, Senol B, Habif S, Mutaf I, Turgan N, Bayindir O: Serum and urinary nitric oxide in Type 2 diabetes with or without microalbuminuria. Relation to glomerular hyperfiltration. J Diabetes Complications 2003, I 7(6):343-348.

42. Fodinger M, Mannhalter C, Wolfl G, Pabinger I, Muller E, Schmid R, Horl WH, Sunder-Plassmann G: Mutation (677 C to T) in the methylenetetrahydrofolate reductase gene aggravates hyperhomocysteinemia in hemodialysis patients. Kidney Int 1997, 52:517-523.

43. Weiss N, Heydrick S, Zhang YY, Bierl C, Cap A, Loscalzo J: Cellular redox state and endothelial dysfunction in mildly hyperhomocysteinemic cystathionine beta-synthase-deficient mice. Arterioscler Thromb Vasc Biol 2002, 22:34-4I.

44. Simon DI, Mullins ME, Jia L, Gaston B, Singel DJ, Stamler JS: Polynitrosylated proteins: characterization, bioactivity and functional consequences. Proc Natl Acad Sci USA 1996, 93:4736-474I.

45. Beckman JS, Koppenol WH: Nitric oxide, superoxide, and peroxynitrite: the good, the bad, and ugly. Am J Physiol 1996, 271:CI424-|437.

46. Beckman JS, Beckman TW, Chen J, Marshall PA, Freeman BA: Apparent hydroxy radical production by peroxynitrite: Implications for endothelial injury from nitric oxide and superoxide. Proc Natl Acad Sci USA 1990, 87:1620-1624.

47. Mujumdar VS, Aru GM, Tyagi SC: Induction of oxidative stress by homocyst(e)ine impairs endothelial function. J Cell Biochem 2001, 82:49l-500.

48. Maejima K, Nakano S, Himeno M, Tsuda S, Makiishi H, Ito T, et al:: Increased basal levels of plasma nitric oxide in Type 2 diabetic subjects. Relationship to microvascular complications. J Diabetes Complications 200 I, I 5: I35-143.

49. Zhang X, Li H, Jin H, Ebin Z, Brodsky S, Goligorsky MS: Effects of homocysteine on endothelial nitric oxide production. $\mathrm{Am} \mathrm{J}$ Physiol Renal Physiol 2000, 279:F67I-678.

50. Li H, Lewis A, Brodsky S, Rieger R, Iden C, Goligorsky MS: Homocysteine induces 3-hydroxy-3-methylglutaryl coenzyme $A$ reductase in vascular endothelial cells. A mechanism for development of atherosclerosis? Circulation 2002, 1 05:1037-1043.

5I. Stuhlinger MC, Tsao PS, Her JH, Kimoto M, Balint RF, Cooke JP: Homocysteine impairs the nitric oxide synthase pathway: role of asymmetric dimethylarginine. Circulation 2001 , I 04(2I):2569-2575.

52. Hayden MR, Tyagi SC: Is type 2 diabetes mellitus a vascular disease (atheroscleropathy) with hyperglycemia a late manifestation? The role of NOS, NO, and redox stress. Cardiovasc Diabetol 2003, 2:2.

53. Noiri E, Satoh H, Taguchi J, Brodsky SV, Nakao A, Ogawa Y, Nishijima S, Yokomizo T, Tokunaga K, Fujita T: Association of eNOS Glu298Asp polymorphism with end-stage renal disease. Hypertension 2002, 40(4):535-540.

54. Brown KS, Kluijtmans LA, Young IS, Woodside J, Yarnell JW, McMaster D, Murray L, Evans AE, Boreham CA, McNulty H, Strain J], Mitchell LE, Whitehead AS: Genetic Evidence That Nitric Oxide Modulates Homocysteine: The NOS3 894TT Genotype Is a Risk Factor for Hyperhomocystenemia. Arterioscler Thromb Vasc Biol 2003, 23(6): $1014-1020$.

55. Stern MP: Diabetes and cardiovascular disease. The "common soil" hypothesis. Diabetes 1995, 44(4):369-374.

56. Gazzaruso C, Garzaniti A, Giordanetti S, Falcone C, Fratino P: Silent coronary artery disease in type 2 diabetes mellitus: the role ofLipoprotein(a), homocysteine and apo(a) polymorphism. Cardiovasc Diabetol 2002, I(I):5.

57. Meigs JB, Jacques PF, Selhub J, Singer DE, Nathan DM, Rifai N, D'Agostino RB Sr, Wilson PW, Framingham Offspring Study: Fasting plasmahomocysteine levels in the insulin resistance syndrome: the Framingham offspring study. Diabetes Care 2001, 24(8): |403-|4|0.
58. Passaro A, D'Elia K, Pareschi PL, Calzoni F, Carantoni M, Fellin R, Solini A: Factors influencing plasma homocysteine levels in type 2 diabetes. Diabetes Care 2000, 23(3):420-42I.

59. Passaro A, Calzoni F, Volpato S, Nora ED, Pareschi PL, Zamboni PF, Fellin R, Solini A: Effect of metabolic control on homocysteine levels in type 2 diabetic patients: a 3-year follow-up. J Intern Med 2003, 254(3):264-27I.

60. Burke AP, Fonseca V, Kolodgie F, Zieske A, Fink L, Virmani R: Increased serum homocysteine and sudden death resulting from coronary atherosclerosis with fibrous plaques. Arterioscler Thromb Vasc Biol 2002, 22(I I): 1936-194I.

61. Tenenbaum A, Fisman EZ, Motro M: Metabolic syndrome and type 2 diabetes mellitus: focus on peroxisome proliferator activated receptors (PPAR). Cardiovasc Diabetol 2003, 2(I):4.

62. Dandona P: Insulin resistance and endothelial dysfunction in atherosclerosis: implications and interventions. Diabetes Technol Ther 2002, 4(6):809-8I5.

63. Hsueh WA, Jackson S, Law RE: Control of vascular cell proliferation and migration by PPAR-gamma: a new approach to the macrovascularcomplications of diabetes. Diabetes Care 200I, 24(2):392-397.

64. Hsueh WA: PPAR-gamma effects on the vasculature. J Investig Med 200I, 49(I): I27-129.

65. Satoh N, Ogawa Y, Usui T, Tagami T, Kono S, Uesugi $H$, Sugiyama $H$, Sugawara A, Yamada K, Shimatsu A, Kuzuya H, Nakao K: Antiatherogenic effect of pioglitazone in type 2 diabetic patients irrespective of the responsiveness to its antidiabetic effect. Diabetes Care 2003, 26(9):2493-2499.

66. Desvergne B, Wahli W: Peroxisome proliferator-activated receptors: nuclear control of metabolism. Endocr Rev 1999, 20(5):649-688.

67. Kersten S, Desvergne B, Wahli W: Roles of PPARs in health and disease. Nature 2000, 405(6785):42I-424.

68. Hsueh WA, Law R: The central role of fat and effect of peroxisome proliferator-activated receptor-gamma on progression of insulin resistance and cardiovascular disease. $\mathrm{Am} \mathrm{J}$ Cardiol 2003, 92(4A):3J-9J.

69. Fonseca V, Keebler M, Dicker-Brown A, Desouza C, Poirier LA, Murthy SN, McNamara DB: The effect of troglitazone on plasma homocysteine, hepatic and red blood cell S-adenosyl methionine, and S-adenosyl homocysteine and enzymes in homocysteine metabolism in Zucker rats. Metabolism 2002, I I (6):783-786.

70. Tao L, Liu HR, Gao E, Teng ZP, Lopez BL, Christopher TA, Ma XL, Batinic-Haberle I, Willette RN, Ohlstein EH, Yue TL: Antioxidative, Antinitrative, and Vasculoprotective Effects of a Peroxisome Proliferator-Activated Receptor-\{gamma\} Agonist in Hypercholesterolemia. Circulation 2003, I 08(22):2805-28I I.

7I. Tyagi SC, Hayden MR: Role of nitric oxide in matrix remodeling in diabetes and heart failure. Heart Fail Rev 2003, 8(I):23-28.

72. Sood HS, Hunt MJ, Tyagi SC: Peroxisome proliferator ameliorates endothelial dysfunction in a murine model of hyperhomocysteinemia. Am J Physiol Lung Cell Mol Physiol 2003, 284(2):L333-34I

73. Hunt MJ, Tyagi SC: Peroxisome proliferators compete and ameliorate Hcy-mediated endocardial endothelial cell activation. Am J Physiol Cell Physiol 2002, 283(4):CI 073-1079.

74. Mujumdar VS, Tummalapalli CM, Aru GM, Tyagi SC: Mechanism of constrictive vascular remodeling by homocysteine: role of PPAR. Am J Physiol Cell Physiol 2002, 282(5):C1009-I0I5.

75. Flynn MA, Herbert V, Nolph GB, Krause G: Atherogenesis and the homocysteine-folate-cobalamin triad: do we need standardized analyses? J Am Coll Nutr 1997, I 6(3):258-267.

76. Tyagi SC: Homocyst(e)ine and heart disease: Pathophysiology of extracellular matrix. Clin Exp Hypertens 1999, 2 I (3): |8I-198.

77. Miller A, Mujumdar V, Palmer L, Bower JD, Tyagi SC: Reversal of endocardial endothelial dysfunction by folic acid in homocysteinemic hypertensive rats. Am J Hypertens 2002, I5(2 Pt I): $157-163$.

78. Mujumdar VS, Tummalapalli CM, Aru GM, Tyagi SC: Mechanism of constrictive vascular remodeling by homocysteine: role of PPAR. Am J Physiol Cell Physiol 2002, 282(5):CI009-1015.

79. Mujumdar VS, Hayden MR, Tyagi SC: Homocyst(e)ine induces calcium second messenger in vascular smooth muscle cells. J Cell Physiol 2000, I 83(I):28-36. 
80. Miller A, Mujumdar V, Shek E, Guillot J, Angelo M, Palmer L, Tyagi SC: Hyperhomocyst(e)inemia induces multi organ damage. Heart Vessels 2000, I5(3): 135-143.

81. Stanger O: Physiology of folic acid in health and disease. Current Drug Metabolism 2002, 3(2):21 I-223.

82. Van Etten RW, De Koning EJ, Verhaar MC, Gaillard CA, Rabelink T]: Impaired NO-dependent vasodilation in patients with Type II (non-insulin-dependent) diabetes mellitus is restored by acute administration of folate. Diabetologia 2002, 45(7): $1004-1010$.

83. Doshi SN, McDowell IF, Moat SJ, Payne N, Durrant HJ, Lewis MJ, Goodfellow J: Folic acid improves endothelial function in coronary artery disease via mechanisms largely independent of homocysteine lowering. Circulation 2002, I 05(I):22-26.

84. Hayden MR, Tyagi SC: Myocardial redox stress and remodeling in metabolic syndrome, type 2 diabetes mellitus and congestive heart failure. Med Sci Monit 2003, 9(7):SR35-52

85. Lindenbaum J, Savage DG, Stabler SP, Allen RH: Diagnosis of cobalamin deficiency: II. Relative sensitivities of serum cobalamin, methylmalonic acid, and total homocysteine concentrations. Am J Hematol 1990, 34:99-107.

86. Savage DG, Lindenbaum J, Stabler SP, Allen RH: Sensitivity of serum methylmalonic acid and total homocysteine determinations for diagnosis of cobalamin and folate deficiencies. Am J Med 1994, 96:239-246.

87. Carmel R, Green R, Rosenblatt DS, Watkins D: Update on Cobalamin, Folate, and Homocysteine. Hematology (Am Soc Hematol Educ Program) 2003:62-81.

88. Flynn MA, Singh A, Slaughter J, King P, Krause G, Herbert V, Thomas $\mathrm{W}$ : Interrelationship of homocysteine-cobalamin-folate indices in human subjects of various ages: can hyper-homocyteinemia be relieved with B-I 2 supplementation? Mo Med 2003, I00(2):155-158.

89. Liaugaudas G, Jacques PF, Selhub J, Rosenberg IH, Bostom AG: Renal insufficiency, vitamin $B(12)$ status, and population attributable risk for mild hyperhomocysteinemia among coronary artery disease patients in the era of folic acid-fortified cereal grain flour. Arterioscler Thromb Vasc Biol 200I, 21:849-85I.

90. Andres E, Noel E, Goichot B: Metformin-associated vitamin B 12 deficiency. Arch Intern Med 2002, 162(19):225I-2252.

91. Filioussi K, Bonovas S, Katsaros T: Should we screen diabetic patients using biguanides for megaloblastic anaemia? Aust Fam Physician 2003, 32(5):383-384.

92. Homocysteine Lowering Trialists' Collaboration: Lowering blood homocysteine with folic acid based supplements: meta-analysis of randomized trials. BMJ 1998, 3 I6:894-898.

93. Johnson MA, Hawthorne NA, Brackett WR, Fischer JG, Gunter EW, Allen RH, Stabler SP: Hyperhomocysteinemia and vitamin B-I 2 deficiency in elderly using Title IIIc nutrition services. Am J Clin Nutr 2003, 77(I):2II-220.

94. Ridker PM, Rifai N, Pfeffer MA, Sacks FM, Moye LA, Goldman S, Flaker GC, Braunwald E: Inflammation, pravastatin, and the risk of coronary events after myocardial infarction in patients with average cholesterol levels. Cholesterol and Recurrent Events (CARE) Investigators. Circulation 1998, 98(9):839-844.

95. Ridker PM, Morrow DA: C-reactive protein, inflammation, and coronary risk. Cardiol Clin 2003, 21(3):3 I5-325.

96. Ridker PM: High-sensitivity C-reactive protein and cardiovascular risk: rationale for screening and primary prevention. Am J Cardiol 2003, 92(4B): I7K-22K.

97. Ridker PM: Clinical application of C-reactive protein for cardiovascular disease detection and prevention. Circulation 2003, 107(3):363-369.

98. Ridker PM, Shih J, Cook TJ, Clearfield M, Downs JR, Pradhan AD, Weis SE, Gotto AM Jr, Air Force/Texas Coronary Atherosclerosis Prevention Study (AFCAPS/TexCAPS) Investigators: Plasma homocysteine concentration, statin therapy, and the risk of first acute coronary events. Circulation 2002, 105(I 5): I776-1779.

99. Verhaar MC, Stroes E, Rabelink TJ: Folates and cardiovascular disease. Arterioscler Thromb Vasc Biol 2002, 22(I):6-13

100. Ajabnoor MA, AL-Ama MN, Banjar Z, Rafee AA, Sheweita SA: Homocysteine level and other biochemical parameters in cardiovascular disease patients with diabetes mellitus. Med Sci Monit 2003, 9(12):CR523-CR527.

10I. Nygard O, Nordrehaug JE, Refsum H, Ueland PM, Farstad M, Vollset SE: Plasma homocysteine levels and mortality in patients with coronary artery disease. N Engl J Med 1997, 337(4):230-236.

102. Dandona P: Editoral. Metabolic Syndrome and Related Disorders 2003, I(2):93.

103. Fonseca VA: Hyperhomocysteinemia and the Metabolic Syndrome: Is There a Connection? Metabolic Syndrome and Related Disorders 2003, I(2):95-96.

104. Joseph J, Joseph L: Hyperhomocysteinemia and cardiovascular disease: New mechanisms beyond atherosclerosis. Metabolic Syndrome and Related Disorders 2003, I(2):97-I04.

105. Becker A, Smulders YM, Guldener CV, Stehouwer CDA: Epidemiology of homocysteine as a risk factor in diabetes. Metabolic Syndrome and Related Disorders 2003, I (2): 105- 20.

106. Randeva HS: Hormonal regulation of homocysteine. Metabolic Syndrome and Related Disorders 2003, I(2): I2I-128.

107. Murthy SN, Matta AS, Mondal D, McNamara DB: Methods in assessing homocysteine metabolism. Metabolic Syndrome and Related Disorders 2003, I(2): 129- I40.

108. Kulkarni K, Richard BC: Lifestyle, homocysteine, and the metabolic syndrome. Metabolic Syndrome and Related Disorders 2003, I(2): $|4|-\mid 47$

109. Asnani S, Chan E, Murthy SN, McNamare DB, Fonseca VA: Effect of Pharmacological treatments for diabetes on homocysteine. Metabolic Syndrome and Related Disorders 2003, I(2): I 49-I58.

110. Chan E, Fonseca VA: Management of hyperhomocysteinemia. Metabolic Syndrome and Related Disorders 2003, I(2): I59-I70.

III. Soinio M, Marniemi J, Laakso M, Lehto S, Ronnemaa T: Elevated plasma homocysteine level is an independent predictor of coronary heart disease events in patients with type $\mathbf{2}$ diabetes mellitus. Ann Intern Med 2004, I 40(2):94-100.
Publish with BioMed Central and every scientist can read your work free of charge

"BioMed Central will be the most significant development for disseminating the results of biomedical research in our lifetime. "

Sir Paul Nurse, Cancer Research UK

Your research papers will be:

- available free of charge to the entire biomedical community

- peer reviewed and published immediately upon acceptance

- cited in PubMed and archived on PubMed Central

- yours - you keep the copyright

Submit your manuscript here:

http://www.biomedcentral.com/info/publishing_adv.asp
BioMedcentral 